University of Michigan Law School

University of Michigan Law School Scholarship Repository

1962

\title{
On Charting a Course through the Mathematical Quagmire: The Future of Baker v. Carr
}

Jerold H. Israel

University of Michigan Law School, israelj@umich.edu

Available at: https://repository.law.umich.edu/articles/237

Follow this and additional works at: https://repository.law.umich.edu/articles

Part of the Civil Rights and Discrimination Commons, Election Law Commons, Fourteenth

Amendment Commons, State and Local Government Law Commons, and the Supreme Court of the

United States Commons

\section{Recommended Citation}

Israel, Jerold H. "On Charting a Course through the Mathematical Quagmire: The Future of Baker v. Carr." Mich. L. Rev. 61 (1962): 107-46.

This Article is brought to you for free and open access by the Faculty Scholarship at University of Michigan Law School Scholarship Repository. It has been accepted for inclusion in Articles by an authorized administrator of University of Michigan Law School Scholarship Repository. For more information, please contact mlaw.repository@umich.edu. 


\section{ON GHARTING A COURSE THROUGH THE MATHEMATICAL QUAGMIRE: THE FUTURE OF BAKER $V$. CARR}

\section{Jerold Israel*}

$\mathrm{T}$ HE Tennessee reapportionment decision, Baker $v$. Carr, ${ }^{1}$ has been popularly characterized as one of the "very few judicial decisions which have fundamentally reshaped our constitutional system."' Newspaper and magazine commentators generally have predicted that the decision of last March is likely to "change the course of our history" by producing a drastic alteration in the balance of power on the state political scene. ${ }^{3}$ While this end may be desirable, ${ }^{4}$ any such estimate of the future impact of the Baker decision, at least insofar as its legal consequence is concerned, ${ }^{5}$ seems not only premature but somewhat exaggerated. The future significance of this decision will ultimately depend upon the

- Assistant Professor of Law, University of Michigan.-Ed.

1969 U.S. 186 (1962).

2 Burnham, One Man, One Vote, 76 Commonweal 145 (1962); Note, 15 Vand. L. Rev. 985 (1962). See, e.g., Ascoli, Reporter's Notes, The Reporter, April 12, 1962, p. 12: “a decision as momentous as the greatest the Supreme Court has handed down .... One of those decisions endowed with the enduring quality that is the stuff of history"; Politics, Not as Usual, 76 Commonweal 339 (1962): "may well be . . . one of the handful of Court rulings which directly changed the course of U.S. history"; Lewis, Decision on Reapportionment Points Up Urban-Rural Struggle, N.Y. Times, April 1, 1962, § 4, p. 3, col. 1. "Historic" and "momentous" were the adjectives widely applied to the decision. The Baker case has frequently been compared in importance to Brown v. Board of Education, 347 U.S. 483 (1954). See Note, 15 VAND. L. REV. 985-86 (1962); Newsweek, April 9, 1962, p. 29.

3 Politics, Not as Usual, supra note 2. See, e.g., Newsweek, supra note 2, at pp. 29-30; N.Y. Times, April 1, 1962, $\& 4$, p. 11, col. 3 (quoting from various other newspapers); Reston, Rural Areas Facing Loss of Political Dominance, N.Y. Times, March 27, 1962, p. 1, col. 6; p. 21, col. I. See also Lewis, supra note 2. But see Bickel, The Great Apportionment Case, New Republic, April 9, 1962, p. 13. The change in the political structure was not expected overnight, however. The commentators have generally noted that there would be "a long, hard fight" in the courts, with appeals and delays, before the decision's impact would be felt on the local political scene. See Politics, Not as Usual, supra; Time, April 6, 1962, p. 17. Subsequent litigation, however, has caused some commentators to suggest that the changes might well occur much earlier than originally predicted. See, e.g., Politics, Not as Usual, supra.

4 See Baker, Rural Versus Urban Polrtical Power 15-82 (1955); Hacker, Message on the Status of the States, N.Y. Times, July 22, 1962, § 6 (Magazine), pp. 15, 27; Lukas, Barnyard Government in Maryland, The Reporter, April 12, 1962, p. 31.

$\sigma$ It is entirely possible that Baker might have a practical significance far beyond its legal importance. The decision may give rise to reapportionment schemes which would not be constitutionally required. But see text at note 155 infra. The concern here, however, will be primarily with the impact that Baker will have insofar as the application of the equal protection clause will invalidate present legislative apportionment. 
manner in which the Supreme Court extricates itself from what Mr. Justice Frankfurter has so colorfully described as the "mathematical quagmire"6 of determining what constitutes invalid state legislative apportionment. And, as the following discussion hopefully will demonstrate, the path to be charted through that quagmire may be far narrower than most commentators and many lower courts have anticipated.

\section{The Gourr's Holding}

In order to evaluate the potential repercussions of the Baker decision, it is necessary at the outset to establish precisely what the Court decided and, more importantly, what remains for future decision. The express holding of the majority opinion ${ }^{7}$ was that a voter's claim of denial of equal protection resulting from allegedly discriminatory apportionment of a state legislature presented a justiciable claim which can be decided by a federal court. ${ }^{3}$ Implicit in this ruling, one would gather, is the further premise that the fourteenth amendment's guarantee of equal protection of the laws may be violated by a scheme of legislative apportionment which creates inequalities of individual voting power through differences in the population of the voting districts represented by state legislators. ${ }^{9}$ Together these principles constitute the entirety of the Baker holding. Nowhere does the Court indicate, by dictum or otherwise, what standards might be used in determining the validity of an apportionment scheme which creates such inequalities.

Since this interpretation of the Baker decision-particularly of what was not decided-serves as the foundation for most of the following discussion, it is important to consider its justification. For, although it is almost unanimously advanced by those who

6369 U.S. at 268 (dissenting opinion).

7 The majority opinion, written by Justice Brennan, was joined in by six members of the Court. 369 U.S. at 187, 241, 251, 265. Three concurring Justices, Douglas, Clark, and Stewart, wrote separate concurring opinions. Justices Frankfurter and Harlan each wrote dissenting opinions in which the other joined. Justice Whittaker did not participate.

8 The Court rejected the argument that it lacked jurisdiction over such a claim, or, if there was jurisdiction, it could not be exercised because the claim presented a "political question." 369 U.S. at 198-237. In addition, the petitioners, as voters, were found to have the proper standing to challenge the legislative apportionment on equal protection grounds. 369 U.S. at 204-08.

9 See 369 U.S. at 237; Cox, Current Constitutional Issues, 48 A.B.A.J. 711, 712 (1962). 
have commented upon the decision, ${ }^{10}$ this restricted view of the Court's holding cannot be accepted without providing a satisfactory explanation of certain language in the majority's opinion.

True, the majority opinion does not contain any lengthy discussion of the criteria for determining what types of legislative malapportionment might constitute a denial of equal protection. In fact, the Court's only direct reference to this subject was by way of rejoinder to the argument that the petitioners' claim presented a "political question" because of the purported absence of "judicially manageable standards for judging" reapportionment cases. The majority simply stated:

"Judicial standards under the Equal Protection clause are well developed and familiar, and it has been open to courts since the enactment of the Fourteenth Amendment to determine, if on the particular facts they must, that a discrimination reflects no policy, but is simply arbitrary and capricious action."11

Thus, the Court did no more than accept, in slightly variant form, the conventional equal protection distinction between permitted "rational classification" (discrimination justified by reasonable differences) and proscribed "invidious discrimination" (discrimination not reasonably justifiable and therefore "arbitrary"). ${ }^{12}$ The Court's indication that this distinction was applicable to claims in the reapportionment setting reveals little about the precise standards to be employed in ascertaining what constitutes invalid apportionment. The crucial factor of what constitutes a "rational" ground for discrimination must vary with the subject matter, ${ }^{13}$ and the specific criteria for determining "ration-

\footnotetext{
10 See, e.g., Burnham, supra note 2, at 147; Katzenbach, Some Reflections on Baker v. Carr, 15 Vand. L. REv. 829, 833 (1962); Lewis, Reapportionment is Gaining Momentum, N.Y. Times, June 17, 1962, § 4, p. 8, cols. 1-5; Aug. 20, 1962, p. 22, col. 1; Newsweek, supra note 2, at p. 32 (quoting Professor Freund). This view of the case is implicit in most discussions by the lower courts. For explicit acceptance by the judiciary, see Lisco v. McNichols, U.S.L. WEEK 2107-08 (D. Colo., Aug. 10, 1962); Maryland Comm. for Fair Representation v. Tawes, Baltimore Daily Record, July 2, 1962, p. 3, col. 4, Anne Axundel County Cir. Ct., aff'd, 182 A.2d 877 (Md. 1962); Mikell v. Rousseau, No. 385, Chittenden County, Vt. Sup. Ct., July 20, 1962, p. 12. But see authorities cited note 14 infra.

11369 U.S. at 226.

12 Cf. Allied Stores, Inc. v. Bowers, 358 U.S. 522, 527 (1959); Morey v. Doud, 354 U.S. 457, 463-64 (1957); Williamson v. Lee Optical, Inc., 348 U.S. 483, 489 (1955).

13 See Safeway Stores, Inc. v. Oklahoma Retail Grocers Ass'n, 360 U.S. 334, 339-40
} 
ality" in the apportionment context are mentioned nowhere in the opinion.

A pronouncement of applicable criteria is not, however, the only means by which an opinion might describe what constitutes an arbitrary apportionment scheme. Establishment of a standard of "invidious discrimination" is also possible by means of the illustrations provided by holdings that particular apportionment schemes are or are not invalid. It is the possible use of precisely this technique which makes troublesome the generally accepted conclusion that the Court in Baker gave no indication of the types of apportionment schemes which must be constitutionally rejected. Both Mr. Justice Clark, who concurred in the majority opinion, and Mr. Justice Harlan, who dissented, understood the majority opinion to hold, albeit $s u b$ silentio, that, as described in the complaint, the Tennessee scheme of apportionment violated the equal protection clause. ${ }^{14}$ Their interpretation apparently rested upon the fact that the majority opinion held not only that the lower court had jurisdiction of the petitioners' claim that inequalities of representation in the Tennessee apportionment scheme rendered it unconstitutional, but also that such a claim, as spelled out in the complaint, constituted "a justiciable cause of action ... upon which [petitioners] would be entitled to relief."15 This latter portion of the Court's holding was construed, by Justices Clark and Harlan, to limit the lower court's task upon remand solely to determining whether petitioners' factual allegations describing the legislative apportionment were true. ${ }^{16}$

(1959); Goesaert v. Cleary, 335 U.S. 464, 467 (1948); Kotch v. Board of River Port Pilot Comm'rs, 330 U.S. 552, 556-57 (1947).

14369 U.S. at 251, 261, 331. See also Baker v. Carr, 206 F. Supp. 341, 345 (M.D. Tenn. 1962); Scholle v. Hare, 367 Mich. 176, 239, 116 N.W.2d 350, 380 (1962) (opinion of Justice Souris); and Note, 15 VAND. L. REv. 985, 989 (1962), which also adopt this view of the majority's holding. But see Sobel v. Adams, Civil No. 182-62-M, S.D. Fla., Aug. 1962, pp. 5-6; Lisco v. McNichols, U.S.L. WEEK 2107-08 (D. Colo., Aug. 10, 1962). Toward the end of his opinion, Justice Harlan criticized the majority for its "failure to come to grips with the question whether the complaint states a claim cognizable under the Federal constitution ..." 369 U.S. at 338 . This presumably refers to the majority's failure to give any explanation for its holding that the Tennessee apportionment was unconstitutional rather than a contradiction of his earlier statement indicating his agreement with Justice Clark that the majority had so held.

15369 U.S. at 197-98. This holding was stressed by Justice Clark. 369 U.S. at 251. Sce also Justice Harlan's opinion at 369 U.S. 186, 330, 338. It has also been relied upon by others who accept the Clark-Harlan view. See authorities cited note 14 supra.

16 See 369 U.S. at 267. Although Justice Harlan did not discuss the point, this con- 
Analyzed in terms of the customary rules of procedure, the holding that the complaint stated a proper "cause of action" certainly would appear to indicate that the majority considered the Tennessee apportionment scheme, as described in the complaint, to be invalid. A holding that a complaint will not be dismissed "for failure to state a claim upon which relief can be granted"17 ordinarily sustains its legal sufficiency, that is, establishes that the plaintiff is entitled to appropriate relief if he can prove the alleged facts. ${ }^{18}$ However, a close reading of the majority opinion in Baker demonstrates that its holding should not be taken in such a customary sense. The Court's holding that a "justiciable cause of action is stated upon which [petitioners] would be entitled to relief" was expressly made "in the light of the district court's treatment of the case."19 The three-judge lower court had dismissed not only for lack of jurisdiction but also for "failure to state a claim."20 As viewed by the majority, the lower court's opinion relied upon the second ground, not because of any position taken upon the constitutionality of Tennessee's legislative apportionment, but because of confusion as to whether Golegrove v. Green ${ }^{21}$ and other decisions thought to be controlling ${ }^{22}$ were based on a lack of federal jurisdiction of claims challenging the constitutionality of legislative apportionment schemes or a discretionary refusal to exercise existing jurisdiction because the subject matter was considered inappropriate for judicial determination. ${ }^{23}$ In reversing on this point of justiciability, the Court merely phrased its conclusion in terms similar to those used by the lower court. It certainly does not seem likely from the tenor of the majority opinion that the Court intended to go beyond reversal of the

clusion as to the issues open on remand is the natural implication of his view of the majority's holding. The lower court apparently also shared this view of the remand. Baker v. Carr, 206 F. Supp. 341, 344 (M.D. Tenn. 1962). See also Scholle v. Hare, 367 Mich. 176, 238, 116 N.W.2d 350, 379 (1962); Note, 15 VAND. L. REv. 985, 998 (1962).

17 FED. R. Crv. P. 12(b)(6).

18 See 1 MOORE, FEDERAL RULES § 12.08 (1961).

18369 U.S. at $197-98$.

20369 U.S. at 196, quoting from the order of dismissal in the lower court. See also the lower court opinion at 179 F. Supp. 824 (M.D. Tenn. 1959).

21328 U.S. 549 (1946).

22 In addition to Colegrove, the lower court relied upon a series of subsequent Supreme Court decisions, mostly per curiam, which relied upon Colegrove. See 179 F. Supp. at 826 (collecting the cases).

23369 U.S. at $197-98$. 
lower court's ruling to hold that not only were claims of denial of equal protection from legislative malapportionment properly to be considered by federal courts, but also that the allegations of fact in the complaint made out such a denial of constitutional rights. ${ }^{24}$ This conclusion is buttressed by the fact that the lower court did not indicate any opinion upon, and certainly did not give any serious consideration to, the constitutional merits of the petitioners' claim. ${ }^{25}$ It has been the policy of the Court in the reapportionment context, as evidenced by two recent decisions, ${ }^{20}$ to refuse to consider any aspect of the merits of the complaint until the lower court has ruled thereon. Thus, despite a somewhat unfortunate use of language, the majority opinion apparently did not decide that the legislative apportionment of Tennessee was unconstitutional. ${ }^{27}$

On the basis of the foregoing analysis, the view generally advanced that the Baker decision neither decided nor indicated what constitutes unconstitutional apportionment should be sustainable. Precise guidelines for ascertaining what constitutes "invidious discrimination" in legislative apportionment were suggested neither by the Court's general commentary on equal protection standards nor by its ruling on the petitioners' complaint. Those state court judges who have suggested, without explanation, that the majority opinion in the Baker decision contains some such standard have, one suspects, read into that opinion their own desire to attribute responsibility for a controversial decision to the Supreme Court

24 Also, the other concurring opinions do not suggest such a broad holding. See 969 U.S. at 241, 265-66.

25 See Baker v. Carr, 179 F. Supp. 824 (M.D. Tenn. 1959). The lower court did note that it agreed with "the plaintiffs' argument that the legislature of 'Tennessee is guilty of a clear violation of the state constitution and of the rights of the plaintiffs." Id. at 828 . There is some question as to whether this reference to plaintiffs' "rights" was to their federal rights or their state rights. The Government had assumed the latter as it argued that the lower court had not considered the merits. Brief for the United States as Amicus Curiae, p. 20, Baker v. Carr, 369 U.S. 186 (1962). In any event, it is clear the court gave no serious consideration to the merits.

26 WMCA, Inc. v. Simon, 370 U.S. 190 (1962) (per curiam); Scholle v, Hare, 369 U.S. 429 (1962) (per curiam).

27 Even if the court had so held, there would be some question as to exactly what this meant. Arguably the mere allegation in the complaint that the apportionment was "arbitrary" would be enough to sustain it against a motion to dismiss. However, as Justice Harlan noted, the facts alleged in the complaint should prevail over any inconsistent legal conclusions, so that a decision upholding the claim would have been based upon the sufficiency of those facts rather than a mere allegation of arbitrariness. See Simmons v. Peavy-Welsh Lumber Co., 113 F.2d 812 (5th Cir. 1940). 
by playing the role of the lower court dutifully following detailed instructions from above. ${ }^{28}$

\section{The Applicable Standards}

Because of the Court's failure to prescribe any standards for determining what constitutes "invidious discrimination" in legislative apportionment, the ultimate significance of the Baker decision is still uncertain. ${ }^{29}$ Although there are many suits pending, ${ }^{30}$ a sufficient number of cases have been decided so as to provide some suggestion as to the standard which might eventually evolve. ${ }^{31}$

28 See Maryland Comm. for Fair Representation v. Tawes, 180 A.2d 656, 668 (Md. 1962); Sweeney v. Notte, 183 A.2d 296, 305 (R.I. 1962) (concurring opinion). Compare Lisco v. McNichols, U.S.L. WEER 2107-08 (D. Colo., Aug. 10, 1962).

20 Another question left unanswered by the opinion is whether a suit challenging a state's legislative apportionment could be dismissed for "want of equity" if the lower court finds that there is no effective remedy for the alleged constitutional violation. See Note, 30 Geo. WAsh. L. REv. 1010, 1017 (1962). The majority opinion does not reject Colegrove v. Green, 328 U.S. 549 (1946), insofar as it is based on this ground. 369 U.S. at 233-36. Also, the Government in its brief took the position that the lower court could always dismiss the Tennessee case if it found all available remedies inappropriate. Brief for the United States as Amicus Curiae, p. 21, Baker v. Carr, 369 U.S. 186 (1962). To date, however, lower courts have had little difficulty devising a remedy even in the most difficult circumstances. See Baker v. Carr, 206 F. Supp. 341 (M.D. Tenn. 1962); Sweeney v. Notte, 183 A.2d 296 (R.I. 1962). Moreover, this has been achieved without using the two remedies most likely to be attacked as inappropriate-an election at large, or direct reapportionment by the court based on its own plan (rather than one devised by the legislature). But cf. Sims v. Frink, Civil Case No. 1744-N, M.D. Ala., July 21, 1962; Scholle v. Hare, 367 Mich. 176, 192, 116 N.W.2d 350, 357 (1962); N.Y. Times, July 22, 1962, p. I, col. 2; p. 46, col. 5. It therefore seems unlikely that the situation will arise where a lower court will find it desirable to dismiss for "want of equity." But cf. Wisconsin v. Zimmerman, Civil No. 3540, W.D. Wis., Aug. 14, 1962.

30 See Reapportionment Efforts at High Pitch, 51 National Crvic Rev. 441-48 (1962); N. X. Times, Aug. 28, 1962, p. 28, col. 3; Oct. 21, 1962, p. 71, col. 1. Few recent court decisions have given rise to as much litigation in so short a time as Baker. Id., May 14, 1962 , p. 1, col. 2.

31 Lisco v. McNichols, 31 U.S.L. WeEk 2107-08 (D.C. Colo., Aug. 10, 1962); WMCA, Inc. v. Simon, 31 U.S.L. WEEK 2121 (S.D.N.Y. June 16, 1962); Sobel v. Adams, Civil No. 182-62-M, S.D. Fla., Aug. 1962; Moss v. Burkhart, Civil No. 9130, D. Okla., June 19, 1962, Aug. 3, 1962; Wisconsin v. Zimmerman, Civil No. 3540, W.D. Wis., Aug. 14, 1962, and Report of the Special Master, July 25, 1962; Baker v. Carr, 206 F. Supp. 341 (M.D. Tenn. 1962); Lein v. Sathre, 205 F. Supp. 536 (D.N.D. 1962); Toombs v. Fortson, 205 F. Supp. 248 (N.D. Ga. 1962); Sims v. Frink, 205 F. Supp. 245 (M.D. Ala. 1962); Stein v. General Assembly, 31 U.S.L. WEeK 2075 (Colo. Sup. Ct. July 6, 1962); Caesar v. Williams, 371 P.2d 241 (Idaho 1962); Harris v. Shanahan, No. 90746, Dist. Ct., Shawnee County, Kan., July 26, 1962; Maryland Comm. for Fair Representation v. Tawes, 180 A.2d 656, decided on remand, Baltimore Daily Record, July 2, 1962, p. 3, cols. 3-6, Anne Arundel County Cir. Ct., aff'd, 182 A.2d 877 (Md. 1962); Scholle v. Hare, 367 Mich. 176, 116 N.W.2d 350 (1962); Levitt v. Attorney Gen., 179 A.2d 286, rehearing denied, 180 A.2d 827 (N.H. 1962); Levitt v. Maynard, 31 U.S.L. WEER 2060 (N.H. Sup. Ct. July 16, 1962); Sweeney v. Notte, 183 A.2d 296 (R.I. 1962); Mikell v. Rousseau, No. 385, Chittenden County, Vt. Sup. C.., 
Lower courts generally, as well as most commentators, have agreed upon either one or the other of two general standards for determining what apportionment inequalities constitute "invidious discrimination." 32 Under the first of these standards, any deviation from what is described as "practical" numerical equality of individual representation would be constitutionally invalid. ${ }^{33}$ The second standard, while basically adhering to a principle of numerical equality of representation, would permit certain deviations-limited but substantial-from "practical equality" where those deviations are based upon "rational" justifications. It is this second, more flexible standard which has received the greater favor of the courts. ${ }^{34}$ A discussion of both standards is in order, however, before considering whether and to what degree judicial support of either is justified.

\section{A. Practical Equality of Individual Representation}

The "practical equality" standard is founded upon the socalled "one man-one vote" principle-that every man is equal and therefore every man's vote should carry the same weight in the election of legislative representatives. ${ }^{35}$ Any inequality in vot-

July 20, 1962. See also Wesberry v. Vandiver, 206 F. Supp. 276 (N.D. Ga. 1962); Sanders v. Gray, 203 F. Supp. 158 (N.D. Ga.), prob. juris. noted, 370 U.S. 921 (1962). [Note: Some of the above cases which appeared in the reporters after the printer had set these footnotes include: Lisco, 208 F. Supp. 471; Sims, 208 F. Supp. 431; IWMCA, Inc., 208 F. Supp. 368; Sobel, 208 F. Supp. 316; Moss, 207 F. Supp. 885.]

32 Bickel, The Great Apportionment Case, New Republic, April 9, 1962, p. 13, appears to be the one exception to this general consensus among commentators.

33 The words "practical" and "substantial" are generally used interchangeably. Sec, e.g., Scholle v. Fare, 360 Mich. 1, 42, 57-60, 104 N.W.2d 68, 84, 92-94 (1960); the dissenting opinion of Justice Smith was sustained on reconsideration of the case at 367 Mich. 176, I16 N.W.2d 350. The phrase "substantial equality" may not always be used by courts in the sense of "practical equality," however. On occasion, it is used in a context suggesting that standard which is described here as "substantial equality" altered by certain "rational" deviations. Cf. Baker v. Carr, 369 U.S. 186, 250 n.5 (1962), and note 40 infra.

34 See note 45 infra.

35 "One man-one vote" refers not merely to the equality of the number of votes cast per individual, but also to the weight attributed to the individual's vote. The concept of "one man-one vote" includes equal voting power as well as equal suffrage. See BAKER, Rural Versus Urban Political Power 5-6 (1955); Burnham, supra note 2. Of course, perfect equality of voting power probably requires a system of proportional representation applied to a state-wide election. As used here, however, equal voting power means merely that equality which results when there are an equal number of people within the various state election districts so that each legislator represents the same number of constituents. Ibid. This definition, in turn, must be further refined by noting that numerical equality 
ing power produced by a principled departure from this concept is considered to constitute arbitrary discrimination. Even under this standard, however, one should not expect that there must be perfect per capita equality of representation. The fourteenth amendment does not require that the principles of equal protection be applied with "mathematical exactness."36 Furthermore, state court decisions enforcing equality of representation provisions in state constitutions have insisted only that legislators represent a "more or less" equal number of constituents so that each man's vote will have "approximately" the same weight. ${ }^{37}$

The "approximate" nature of the equality of representation even under the "practical equality" test should be stressed. Unless voting districts are to be constantly changed without consideration of natural boundaries, it is fortunate indeed to achieve anything less than a twenty-five percent difference in individual voting power ${ }^{38}$ - even without considering the further disparity resulting from population shifts between apportionments. This can be easily illustrated by the following example. Assume that a state has four major population centers, each traditionally serving as

of constituencies may be measured in terms of total adult population, that portion of the population eligible to vote, those who have registered to vote, or those who actually voted in previous elections. All four bases of calculation either are used or have been suggested for use. See BAKER, State Constriutions: ReApportionment 6-7 (1960); Romani, Legislative Representation, in Salient Issues of ConstrTutional Reviston 34, 36 (Wheeler ed. 1961); Harvey, Reapportionments of State Legislatures-Legal Requirements, 17 LAw \& CONTEMP. Prob. 364, 366 (1952). All are compatible with the practical implementation of the "one man-one vote" concept. See Sanders v. Gray, 203 F. Supp. 158, 170 (N.D. Ga. 1962); Maryland Comm. for Fair Representation v. Tawes, 180 A.2d 656, 668 (Md. 1962); Baker, State Constitutions: ReApportionment, supta, at 6-7. But see Romani, supra, at 36-37.

38 Baker v. Carr, 369 U.S. 186, 260 (1962) (concurring opinion). See Allied Stores, Inc. v. Bowers, 358 U.S. 522, 527-28 (1959); Skinner v. Oklahoma ex rel. Williamson, 316 U.S. 535, 540 (1942).

37 See, e.g., People ex rel. Woodyatt v. Thompson, 155 Ill. 451, 463-66, 476-82, 40 N.E. 307, 310.11 (1895); Parker v. State ex rel. Powell, 183 Ind. 178, 192-200, 32 N.E. 836, 840-43 (1892); Giddings v. Blacker, 93 Mich. 1, 6-8, 52 N.W. 944, 946 (1892); People ex rel. Carter v. Rice, 135 N.Y. 473, 498-506, 31 N.E. 921, 928-31 (1892); State ex rel. Bowman v. Dammann, 209 Wis. 21, 243 N.W. 481 (1932).

38 The English experience is illustrative. The 1944 Redistribution Act was based on the principle of "representation by population" with respect for local geographical boundaries as far as practicable. Nevertheless the act required only that districts should not deviate more than $25 \%$ from the electoral quota (population divided by number of districts). However, even the $25 \%$ standard was found "too restrictive." See Baker v. Carr, 369 U.S. 186, 304-05 (1960) (dissenting opinion of Justice Frankfurter). See also cases cited in note 34 supra. 
the nucleus of a voting district. Assume also that the state constitution provides for six legislators and that the state population is 600,000 , so that ideally each legislator should represent 100,000 people. District $A$ has 120,000 people, district $B$ has 130,000 people, district $G$ has 170,000 people, district $D$ has 180,000 people. Can the state under the "practical equality" standard "reasonably" apportion two representatives each to districts $C$ and $D$ and one representative apiece to $A$ and $B$ ? If so, the legislator from $B$ will represent over half again as many people $(130,000)$ as a single legislator from district $G(85,000) .{ }^{38}$ Yet, the concept of figuring to the nearest whole number is not uncommon. ${ }^{10}$ It may be possible, of course, to reduce the differences in voting power by creating floterial districts. ${ }^{41}$ In this case, for example, one representative apiece may be apportioned to each of the four districts individually, and the two remaining representatives might be elected from two floterial districts, one composed of districts $A$ and $D$ and the other of districts $B$ and $C$. But then again districts $A$ and $D$, or $B$ and $C$, may not be contiguous, or there may be regional differences which would not make the sharing of a representative feasible. Moreover, it seems likely that the broad discretion left to a legislature even under a "practical equality" standard includes the power to reject completely the use of floterial districts. Also, the alternative of redefining the state voting districts so that the population of each would be an even quotient of 100,000 seems infeasible if the present boundaries are both traditional and natural. ${ }^{42} \mathrm{~A}$ court could not reasonably require

\footnotetext{
39 Also, under this distribution, $58 \%$ of the population would elect $67 \%$ of the legislature. Of course, in the usual situation there would probably be many districts close to the ideal population per representative so that while there may be a $50 \%$ deviation in population of particular districts, it would still take at least $45 \%$ of the population to elect $50 \%$ of the legislature.

40 See, e.g., recent statutes cited in Baker v. Carr, 206 F. Supp. 341, 345 (M.D. Tenn. 1962); Sobel v. Adams, Civil No. 182-62-M, S.D. Fla., Aug. 1962, p. 2. See also Willcox, Last Words on the Apportionment Problem, 17 LAw \& Contemp. Prob. 290, 291-93 (1952). See generally Asbury Park Press, Inc. v. Woolley, 33 N.J. 1, 8, 161 A.2d 705, 708 (1960) (listing the various methods of dealing with fractions in apportionment).

41 On the functioning of "combination" or "floterial" districts, see BOYD, PatTERNs OF APPORTIONMENT 16 (1962). Another method of equalizing individual voting power is to vary the weight of a legislator's vote according to the comparative size of the population of the district he represents. See Tyler, What Is Representative Government?, New Republic, July 16, 1962, p. 15.

42 See In the Matter of Baird v. Board of Supervisors, 138 N.Y. 95, 105-14, 33 N.E. 827 , 830-33 (1893).
} 
the state to take one part of a town and include it in a voting district dominated by another town miles away, solely for the purpose of avoiding that inequality in representation which results from the rounding off of fractions. In fact, to require redistricting in such situations would only encourage political gerrymandering. Thus, in summary, even under the standard of "practical equality" of representation the actual result may be far from the ideal of the "one man-one vote" principle.

Even with this concession to the pragmatic, "practical equality" of representation as a standard for judging the constitutionality of legislative apportionment has been more talked about than acted upon. Although this concept was pressed by many newspaper and magazine commentators as the eventual progeny of the Baker decision, ${ }^{43}$ at least two of the Justices who concurred in the majority opinion and both of those dissenting indicated in separate opinions that they would not accept such a standard. ${ }^{44}$ Moreover, this standard has fared little better in other courts, state or federal.45 In fact, only one or possibly two courts have accepted the "practical equality" standard as a requirement inherent in the equal protection clause. Its principal judicial support is derived from the Michigan Supreme Court decision in Scholle v. Hare, ${ }^{40}$ and even there it is not entirely clear that the standard was adopted.

43 See Lewis, Decision on Reapportionment Points up Urban-Rural Struggle, N.Y. Times, April 1, 1962, § 4, P. 8, col. 1; Note, 15 VAND. L. Rev. 985, 986 (1962). See also N.Y. Times, Sept. 10, 1962, p. 46, col. 6.

14 See the opinion of Justice Clark, 369 U.S. at 252-53, 253 n.4, 258 (1962); the opinion of Justice Stewart, 369 U.S. at 265-66; the opinion of Justice Frankfurter, 369 U.S. at 266, 301-24; the opinion of Justice Harlan, 369 U.S. at 334, 336, 345-48. The opinion of Justice Douglas is rather confusing on this point. At one place in his opinion he notes that "universal equality is not the test; there is room for weighting." 369 U.S. at 244-45. Yet later he suggests the goal of "substantial equality" of representation, 369 U.S. at 250 n.5. See also his dissents in South v. Peters, 939 U.S. 276, 277 (1950); MacDougall v. Green, 335 U.S. 281, 288 (1948).

45 See Lisco v. McNichols, U.S.L. WeEk 2107-08 (D. Colo. Aug. 10, 1962); WMCA, Inc. v. Simon, 31 U.S.L. WEEK 2121 (S.D.N.Y. June 16, 1962); Baker v. Carr, 206 F. Supp. 341 (M.D. Tenn. 1962); Toombs v. Fortson, 205 F. Supp. 248 (N.D. Ga. 1962); Sims v. Frink, 205 F. Supp. 245 (M.D. Ala. 1962); Caesar v. Williams, 371 P.2d 241 (Idaho 1962); Maryland Comm. for Fair Representation v. Tawes, 180 A.2d 656 (Md. 1962); Levitt v. Attorney General, 179 A.2d 286 (N.H. 1962); Sweency v. Notte, 183 A.2d 296 (R.I. 1962).

40367 Mich. 176, 116 N.W. 350 (1962), stay granted pending disposition of petition for certiorari to the United States Supreme Court, N.Y. Times, July 28, 1962, p. 9, col. 1 . The case was originally decided in favor of the Secretary of State, 360 Mich. 1, 116 N.W.2d 63, but was remanded by the Supreme Court "for further consideration in the light of Baker v. Carr," 369 U.S. at 429. 
The Michigan court held invalid a state constitutional provision apportioning the state senatorial seats among enumerated districts. The Michigan lower house is apportioned on a population basis, ${ }^{47}$ but the apportionment of the senate by geographical area clearly did not provide for anything approaching per capita equality of representation. The two opinions for the majority rejected the senatorial apportionment because "the arrangement of the [voting] districts was made without any discernible or conceivable basis, let alone upon any rational basis" 48 -a ground which is consistent with other possible equal protection standards besides "practical equality" of representation..$^{49}$ However, the court seemingly adopted the "practical equality" standard when it warned the legislature that future apportionment of the state senate would certainly be invalid if any legislator had a constituency twice the size of another. Thus, one of the opinions stated:

"When a legislative apportionment provides districts having more than double the population of others, the constitutional range of discretion is violated. This is not to say less than

\footnotetext{
47 The one hundred and ten seats in the Michigan House of Representatives are apportioned among election districts which must "contain as nearly as may be an equal number of inhabitants." However, the "representative districts" also must "consist of convenient and contiguous territory," with "no township or city ... divided in the formation of a representative district, except ... when a city is composed of territory in more than one county ...." Moreover, each representative district is "entitled to a separate representative when it has attained a population equal to a moiety of the ratio of representation" (total population divided by one hundred). Mich. Const. art. V, $\$ 3$ (1908). Of course, these latter provisions bar perfect implementation of the basic population standard. See Romani, Legislative Representation, in SALIENT Issues of ConstrTutional Revision 34, 37-38 (Wheeler ed. 1961). The departure is not so significant, however, as to violate a "practical equality" test. Cf. BAKER, State Constitutions: ReApportionment 7-8 (1960). But cf. N.Y. Times, Aug. 30, 1962, p. 28, col. 6 (letter to the editor from counsel for petitioner in the Scholle case).

48367 Mich. at 242-43, 116 N.W.2d at 381 (concurring opinion of Justice Souris). There was no one opinion in which all members of the four-man majority concurred. Justices Souris and Kavanaugh each wrote an opinion in which one other member of the majority concurred.

40 Moreover, both opinions contain certain other statements which might indicate that such non-population factors as area might be considered in apportionment. See Justice Kavanaugh's opinion, at 367 Mich. 186, relying on his earlier opinion which seemed to suggest apportionment might be justified by a "rational correlation ... . [to] representation of area, political units, interests, population, or any combination of these." 360 Mich. at 40, 104 N.W.2d at 83. See also Justice Souris' opinion at 867 Mich. at 242, 116 N.W.2d at 381, where he claims to leave open the question of "whether a State may, as a matter of State policy, have as its objective in classifying its people into electoral districts, the dilution of the voting strength of some in favor of others." But see his immediately preceding comments.
} 
such 2-to-1 ratio is constitutionally good. It is to say only that peril ends and disaster occurs when that line is crossed."50

This test of a two-to-one ratio or less, taken from state cases interpreting a state requirement of "practical equality," 51 certainly appears to impose that same standard as a requirement of the equal protection clause. ${ }^{.2}$ The Michigan court's suggestion that it might permit deviation from absolute numerical equality of representation up to the point of a two-to-one ratio does not indicate otherwise. In a state such as Michigan, where the state constitution prohibits the division of a county in drawing an election district, ${ }^{\mathrm{b} 3}$ something approaching a two-to-one deviation in numerical representation for a small portion of the electorate may be as practical an application of the one man-one vote principle as can reasonably be achieved. ${ }^{.4}$

The majority opinions of the Michigan court relied in large part on the political theory behind the one man-one vote concept to justify the imposition of a two-to-one ratio as the outer limit for inequality of representation. Thus, the justices quoted with approval such earlier judicial statements as one that equality of

50367 Mich. at $188-89,116$ N.W.2d at 355 . This requirement was accepted by all the members of the majority. See 367 Mich. at 243,116 N.W.2d at 382.

51 See Williams v. Secretary of State, 145 Mich. 447, 108 N.W. 749 (1906); Giddings v. Blacker, 93 Mich. 1, 52 N.W. 944 (1892). The test was also supported by reference to the statement in the dissenting opinion in MacDougall v. Green, 335 U.S. 281 (1948), that a "State law giving some citizens twice the vote of other citizens . . . would lack that equality which the Fourteenth Amendment guarantees." Id. at 288.

52 It has been argued that the Michigan court imposed this standard solely as a requirement of the 1908 state constitutional provision, which was resuscitated once the 1952 provision was rejected as unconstitutional. See N.Y. Times, Aug. 30, 1962, p. 28, col. 6 (statement by counsel for petitioner Scholle). However, the court clearly states at various points that this standard is a requirement of the federal equal protection clause. Thus, Justice Kavanaugh summarizes the majority holding as follows: "We hold in final sum. mation that the Fourteenth Amendment and our own corresponding pledge of the protection of equal laws ... do require that the senatorial districts of Michigan be so arranged as to be consistent with the foregoing maximum 2-to-1 ratio." 367 Mich. at $189-90,116$ N.W.2d at $355-56$. It should be noted that this two-to-one requirement was derived from an opinion interpreting the fourteenth amendment as well as opinions interpreting the state constitution. See note 51 supra.

83 Mich. Const. art. 5, § 2 (1908) prohibits the creation of a senatorial district which includes portions of two different counties. See Williams v. Secretary of State, $145 \mathrm{Mich}$. 447, 108 N.W. 749 (1906). The majority in Scholle treated the 1908 provision as operative once the present provision, adopted in 1952, was found invalid. See 367 Mich. at 186, 243, 116 N.W.2d at 354,883 .

54 See In the Matter of Baird v. Board of Supervisors, 138 N.Y. 95, 112-14, 33 N.E. 827, 832-33 (1893); State ex rel. Bowman v. Dammann, 209 Wis. 21, 243 N.W. 481 (1932). 
voting "lies at the basis of our free government."55 And it was in the light of these statements that the majority concluded that the equal protection clause requires approximate equality of individual voting power in order to "ensure that reasonably uniform right of governmental representation which came to life by impact of the Declaration of Independence."56

A similar rationale was expressed in Moss $v$. Burkhart, ${ }^{57}$ an Oklahoma federal district court decision in which, when the opinion is read in the light of the decree, it may be argued that the court adopted the "practical equality" standard as a requirement of the equal protection clause. ${ }^{58}$ In the Moss decision the court concluded that numerical equality of representation was the basic requirement of equal protection "because under our democratic institutions and republican form of government, the suffrage right of the individual is, and must be the keystone,- the common denominator, of self-government." 59

This view of constitutionally-prescribed democratic government as requiring complete per capita equality of representation in the legislature has been popularly criticized on the ground that it ignores the historical precedent of our federal legislative sys-

55367 Mich. at 187, 116 N.W.2d at 354, quoting from Giddings v. Blacker, 98 Mich. 1, 7, 52 N.W. 944, 946 (1892).

56367 Mich. at 189,116 N.W.2d at 355.

57 Civil No. 9130, D. Okla., June 19, 1962.

58 The court's opinion is rather ambiguous as to whether "practical equality" of representation is required under the fourteenth amendment. The opinion noted that "while mere numerical disparity in voting strength is not, per se, invidiously discriminatory, it is, to be sure, cogent evidence of it and ... may be sufficiently disproportionate to constitute a prima facie showing." Id. at 5. The court further stated that its "guideline" in applying the equal protection clause would be the standard of the Oklahoma constitution which makes "the principle of numerical equality ... the rule, and any deviation ... the exception ...."Id. at 6 . However, at the same time, the opinion recognized the presence of "relevant countervailing factors, such as geography, economics, mass media and functional or group voting strength." Ibid. Since no justifications were offered for the numerical inequality in the Oklahoma apportionment, the court did not have to consider precisely what weight would be given to such factors, although it did note that they "could not overcome the basic principle underlying the right of an individual to cast an effective vote." Ibid. In the light of the vagueness of this opinion, it is rather surprising to find that the final decree requires the legislature to be "reapportioned on the general principle of substantial numerical equality, to the end that each voter shall have approximately the same power and influence in the election of the members of the two houses." Pp. 2-3 of Final Decree. Moreover, the decree specifically states that this order is based on the fourteenth amendment as well as the Oklahoma constitution.

59 Moss v. Burkhart, Civil No. 9130, D. Okla., June 19, 1962, pp. 5-6. 
tem. ${ }^{60}$ Certainly, it has been argued, it would be anomalous to hold that the Constitution condemns a state's adoption of a bicameral legislature with one house apportioned essentially on the basis of population ${ }^{61}$ and the other apportioned with reference to the representation of political subdivisions ${ }^{62}$ when that same Constitution adopted just such a legislative system, with substantial numerical inequality of representation in the Federal Senate, which has been accepted without question since its ratification. ${ }^{63}$

Reliance upon the federal legislative system as a historical precedent has, in turn, been sharply criticized, particularly by commentators advocating the "practical equality" standard. "The essence of their argument against the "federal precedent" is summed up in a single sentence: "the 13 original states created the United States; the counties were created by the states." states were independent sovereignties and could demand, right-

60 See Krock, Apportionment Test, N.Y. Times, May 27, 1962, \& 4, p. 13, col. 1; Lewis, Reapportionment Is Gaining Momentum, N.Y. Times, June 17, 1962, \& 4, p. 8, cols. 1-5; Hacker, Message on the State of the States, N.Y. Times, July 22, 1956, \$ 6 (Magazine), pp. 15, 27, col. 4. See also Baker v. Carr, 369 U.S. 186, 333 (1962) (dissenting opinion); Scholle v. Harc, 367 Mich. 176, 215, 217-19, 116 N.W.2d 350, 368-70 (1962) (dissenting opinion); Boyd, op. cit. supra note 41 , at 4-5.

61 The House of Representatives is not apportioned strictly on population since each state is guaranteed one representative regardless of its population. U.S. CoNST. art. II, § 2. Today, however, this affects only two seats out of the 435. Message of the President, H.R. Doc. No. 46, 87th Cong., lst Sess. 2 (1961).

62 In state legislatures following this pattern the representation by political units is sometimes in the house of representatives while the senate is the branch apportioned on a population basis. See, e.g., VT. ConsT. ch. II, $\S \S 13,14,18$. For the purposes of this discussion, however, the legislative branch apportioned on a population standard will be referred to as the "lower house" while the other branch will be described as the "upper house."

03 See Maryland Comm. for Fair Representation v. Tawes, Baltimore Daily Record, July 2, 1962, p. 3, col. 4, Anne Arundel County Cir. Ct., aff'd, 182 A.2d 877 (Md. 1962); Memorandum opinion of the Special Master Part III, Wisconsin v. Zimmerman, Civil No. 3540, W.D. Wis., Aug. 3, 1962, p. 14. While the equal protection clause does not apply to the federal government, a similar restriction upon governmental discrimination may be imparted from the fifth amendment due process clause. See Bolling v. Sharpe, 347 U.S. 497 (1954).

The ratio of deviation in numerical representation in the federal Senate is greater than that in most states. Sce, e.g., Maryland Comm. for Fair Representation v. Tawes, supra. A Senator from New York represents approximately seventy-four times as many people as the Senator from Alaska. H.R. Doc. No. 46, supra note 61, at 2.

ot See, e.g., Tyler, What Is Representative Government?, New Republic, July 16, 1962, pp. 15, 17; Editorial Comment, The Apportionment Revolution, 51 Natronat Crvic Rev. 244 (1962); New Republic, June 11, 1962, p. 2. See also McKax, ReApPoRTIONMENT AND the Federal ANalogy 1-10 (1962).

os Tyler, supra note 64 , at 17 . 
fully or not, ${ }^{68}$ equal representation in the Senate as the price for surrendering their sovereignty to a central government. On the other hand, counties and other political subdivisions of the state are not and never were regarded as sovereigns. They are, to the contrary, mere creations of the state, subject to contraction, expansion, or dissolution almost at the whim of the state. ${ }^{67}$ They have no special position by virtue of history which entitles them to representation other than in accordance with the size of their populace. ${ }^{68}$ Therefore, the argument concludes, the analogy of the federal legislative system is both an "irrelevant and improper" basis for judging the constitutionality of discrimination in state legislative apportionment. ${ }^{69}$

In reply to this criticism, the question has been raised as to how an institutional scheme may be rational if it is the product of compromise between equal forces and arbitrary when it results from a grant made within the discretion of the granting body. ${ }^{70}$

66 The senatorial apportionment has even been characterized by one advocate of practical equality of representation as "a necessary evil, made historically imperative as part of the price of union." Tyler, supra note 64, at 17 . See also the original opinion of Justice Black of the Michigan Supreme Court in Scholle v. Hare, 360 Mich. 1, 122-23, 104 N.W.2d 63, 126-27 (1960).

67 Hunter v. Pittsburgh, 207 U.S. 161, 178 (1907).

68 Opponents of the "federal analogy" contend that there is nothing inherent in the concept of a bicameral legislature which prevents apportionment of both houses on a population basis. The difference in the bases of representation in each branch which is needed to provide a system of checks and balances can be obtained "by making one house more numerous and the other less; by electing men to one house from smaller, perhaps more homogenous districts ...." Tyler, supra note 64 , at 18 . See also McKAY, op. cit. supra note 64, at 9-10. Many bicameral legislatures have been apportioned on this basis. See, e.g., Mrch. Const. art. 5, $\$ \S 2,3$ (1908). As of 1960, there were nine bicameral legislatures in which both houses were required to be apportioned on a strict population basis. BAKER, State Constitutrons: ReApPoRtionment 5 (1960). Moreover, there were twelve bicameral legislatures in which a population basis was legally required except that each city, county, or other political subdivision was guaranteed a seat in one of the legislative branches. Brief for the United States as Amicus Curiae, pp. 25-27, Baker v. Carr, 369 U.S. 186 (1962). It should be noted, however, that the concept of checks and balances within the legislature is not so much an attribute of the concept of bicameralism in itself as it is of the different bases of representation within the legislature. BAKER, $O p$. cit. supra, at 13. The same checks and balances could be provided in a unicameral legislature if the seats were apportioned on two different bases. Cf. N.Y. Times, Aug. 26, 1962, p. 42, col. 5; Aug. 28, 1962, p. 6, col. 1.

69 Tyler, supra note 64, at 17, quoting Professor David of the University of Virginia.

70 See generally Scholle v. Hare, 367 Mich. 176, 222, 116 N.W. 350, 371 (1962) (dissenting opinion); Maryland Comm. for Fair Representation v. Tawes, Baltimore Daily Record, July 2, 1962, p. 3, cols. 3-6, Anne Arundel County Cir. Ct., aff'd, 182 A.2d 877 (Md. 1962). Cf. Sanders v. Gray, 203 F. Supp. 158, 169 (N.D. Ga. 1962), making a similar argument with respect to state election systems patterned after the Electoral College. 
Surely, it is argued, the numerical inequality in representation in the Senate is considered to be based upon a rational classification for reasons in addition to the fact that it was a political necessity in 1789. This classification must be founded on the special functions performed by the states which entitle them to equal representation irrespective of their population. Political subdivisions, such as counties, whether created by the state or not, perform much the same functions within the state system as do the states within the federal system. ${ }^{71}$ Therefore, the contravening argument continues, they rationally may be granted the same type of representation in the state counterpart of the Senate. As one court has put it, the "mere use of the word 'sovereignty' can[not] as a practical matter sustain the Federal System and invalidate the States."72

This reply does not go far enough. Actually, both the popular reliance upon the historical precedent of the Federal Senate to attack the "practical equality" standard and the reply to that attack have missed the point. While the heated debate over the validity of the "federal system" as a meaningful historical precedent has attracted much attention, the fact of the matter is that the rejection of the "practical equality" standard does not rest on that precedent as such. Actually, with one exception, ${ }^{73}$ the courts refusing to accept the "practical equality" standard have not relied upon the federal analogy to sustain their position. ${ }^{74}$ Neither have

71 But see Bonfield, Baker v. Carr: New Light on the Constitutional Guarantee of Republican Government, 50 CALIF. L. REv. 245, 260 (1962).

72 Maryland Comm. for Fair Representation v. Tawes, Baltimore Daily Record, July 2, 1962, p. 3, col. 4, Anne Arundel County Cir. Ct., aff'd, 182 A.2d 877 (Md. 1962).

73 Maryland Comm. for Fair Representation v. Tawes, supra note 72. Cf. Sanders v. Gray, 203 F. Supp. 158 (N.D. Ga. 1962).

74 See, e.g., Lisco v. McNichols, 31 U.S.L. WeEk 2107-08 (D. Colo. Aug. 10, 1962); Sims v. Frink, Civil No. 1744-N, M.D. Ala. July 21, 1962; WMCA, Inc. v. Simon, 31 U.S.L. WEEK 2121 (S.D.N.Y. June 16, 1962); Sobel v. Adams, Civil No. 182-62-M, S.D. Fla. Aug. 1962; Baker v. Carr, 206 F. Supp. 341 (M.D. Tenn. 1962); Toombs v. Fortson, 205 F. Supp. 248 (N.D. Ga. 1962); Caesar v. Williams, 371 P.2d 241 (Idaho 1962); Levitt v. Maynard, 31 U.S.L. WEEK 2060 (Sup. Ct. N.H. July 16, 1962); Sweeney v. Notte, 183 A.2d 296 (R.I. 1962). In most of these cases the court did not even mention the federal system and its possible value as a precedent. The Sims court went farther, however, and explicitly rejected any "federal analogy" on the grounds that it could not survive "the most superficial examination into the history of the requirement of the federal Constitution ... [or] a comparison of the different political nature of states and counties." Sims v. Frink, supra, at 11. Two members of the present Supreme Court have rejected the reliance upon the federal system as a precedent indicative of what constitutes valid state apportionment, but it seems likely that they will favor the "practical equality" standard. See MacDougall v. 
they insisted that the sole alternative to "practical equality" would be a duplication of the federal system, with one house based essentially upon population and the other based upon representation of political subdivisions. These courts have not looked to the historical sanctity of the federal system as such, but rather to the underlying considerations which support the utilization of that system irrespective of the peculiar circumstances of its adoption. The satisfactory operation of Congress serves to illustrate the general rationality of a system of apportionment which gives some weight (although not necessarily the same as in the federal system) to factors other than population (including, but not limited to, representation of political subdivisions).

\section{B. Rational Deviations From Equality}

To date, the overwhelming majority of courts which have dealt with contested apportionment schemes in the wake of the Baker decision have given consideration to factors other than population in determining whether numerical inequalities in representation constitute "invidious discrimination" or "rational classification." "75 In general, these courts have adopted an equal protection standard which may be described briefly as emphasizing practical equality, but permitting certain so-called "rational deviations" from such equality. ${ }^{76}$ As this description indicates, the standard does not totally discard the one man-one vote concept. On the contrary per capita equality of representation is considered "the starting point in determining the constitutionality of any apportionment" since it is one of the "fundamental ideals of American life."77 Any "serious departure" from apportionment accord. ing to population is automatically "subject to question" and

Green, 335 U.S. 281, 287-89 (1948) (dissenting opinion of Justice Douglas, joined by Justices Black and Murphy). See also Baker v. Carr, 369 U.S. 186, 241 (1962).

75 See cases cited supra notes 73 and 74.

76 This standard was first developed in the argument of the Solicitor General in Baker. See Brief for the United States as Amicus Curiae, pp. 25-36, Baker v. Carr, 369 U.S. 186 (1962). See also Cox, Current Constitutional Issues, 48 A.B.A.J. 711, 712 (1962).

$7 \tau$ Brief for the United States as Amicus Curiae, p. 25, Baker v. Carr, 369 U.S. 186 (1962). See also Caesar v. Williams, 371 P.2d 241, 249 (Idaho 1962); Maryland Comm. for Fair Representation v. Tawes, Baltimore Daily Record, July 2, 1962, p. 3, col. 3, Anne Arundel County Cir. Ct., aff'd, 182 A.2d 877 (Md. 1962) (quoting the Solicitor General's argument); see the earlier opinion of the Maryland case at 180 A.2d 656, 668 (1962). 
renders the apportionment unconstitutional unless it is shown to have a "rational justification."78 Even an otherwise "rational justification," however, will not warrant deviations from numerical equality of representation that are found to be "too extreme."79

Obviously, one problem in determining the significance of a standard permitting some numerical inequality in representation beyond that necessitated by the practicalities of apportionment lies in ascertaining what constitutes a "rational justification" for such an inequality. The Solicitor General, who first introduced the "rational deviations" standard in the Government's amicus curiae brief in the Baker case, ${ }^{80}$ suggested that the following considerations might constitute justifiable non-population bases for representation: "The claims of historically separate units such as towns and counties to have equal recognition, the desirability of distributing political power geographically, the need to prevent a single large city or two from dominating the state," and possibly the share of the state's costs which are paid by the various election districts. $^{81}$ In addition, it has been suggested that even the desire to protect certain minority economic interests may justify a departure from numerical equality. ${ }^{82}$ Most of these "factors" have already been accepted by the courts and there are indications the others will be accepted. ${ }^{83}$

78 Brief for the United States as Amicus Curiae, p. 25, Baker v. Carr, 369 U.S. 186 (1962). See Sims v. Frink, Civil No. 1744-N, M.D. Ala., July 21, 1962; Sweeney v. Notte, 183 A. 2d 296 (R.I. 1962). A significant departure from the "practical equality" standard has been viewed as establishing "a prima facie case of invidious discrimination" shifting the burden to the defendants "to show that there exists some rational basis for these [numerical] disparities [in representation]." Lisco v. McNichols, 31 U.S.L. WEEK 2107-08 [Civil No. 7501, p. 14] (D. Colo. Aug. 10, 1962).

70 See Cox, supra note 76, at 712. See generally the cases cited in notes 74 and 75 supra and the text at notes $90-95$ infra.

80 See note 76 supra.

81 Cox, supra note 76, at 712. For another list, see Baker v. Carr, 369 U.S. 186, 346 (1962) (dissenting opinion of Justice Harlan).

82 See Lisco v. McNichols, 31 U.S.L. WeEk 2107-08 (D. Colo., Aug. 10, 1962); Sobel v. Adams, Civil No. 182-62-M, S.D. Fla., Aug. 1962, pp. 10-11; Baker v. Carr, 369 U.S. 186, 346-47 (1962) (dissenting opinion).

83 See Baker v. Carr, 206 F. Supp. 341, 345, 347 (M.D. Tenn. 1962), recognizing as "rational" the representation of political units and/or geographical area, and the distribution of political power between the urban and rural population; Lisco v. McNichols, supra note 82 , recognizing as a relevant factor representation of certain industrial interests; Sobel v. Adams, supra note 82 , at 10-11, recognizing as a relevant consideration the representation of general regional interests; Caesar v. Williams, 371 P.2d 241, 248-49 (Idaho 1962), recognizing as rational the protection of sparsely settled areas; Levitt v. Maynard, 
Numerous reasons have been advanced to justify these considerations as providing "rational" bases for apportioning a legislature. ${ }^{84}$ In general, these reasons are founded upon the concept of granting special political security to minorities, particularly the inhabitants of the more remote and sparsely populated sections of a state. The deficiencies of an apportionment scheme based predominantly on population in preserving the legitimate interests of the sparsely populated areas-even to the point of creating districts so spacious that legislators are not readily accessible to their constituencies-have been recognized by the courts. ${ }^{85}$ Consequently, partial reliance upon the factors suggested by the Solicitor General in apportioning state legislatures has been justified as necessary to achieve the ideal of a government which maintains a responsiveness to the will of its constituency as a whole, without a "loss of responsiveness to lesser voices, reflecting smaller bodies of opinion, in areas that constitute their own legitimate concern."88

The difficulty with a "rational deviations" standard lies not so much in defining the "rational" justifications for departure from numerical equality in representation as it does in determining how far the departures resting upon these justifications may be carried. ${ }^{87}$ The Government, in its brief in Baker, seemed to

31 U.S.L. WEEK 2060 (Sup. Ct. N.F. July 16, 1962), recognizing as "rational" the proportion of the total taxes paid by a district. See also cases cited in note 74 supra.

84 See, e.g., the various arguments offered by Judge Duckett of the Circuit Court of Anne Arundel County, Maryland, in his two opinions in Maryland Comm. for Fair Representation v. Tawes, 30 U.S.L. WEEK 2587 (Anne Arundel County Cir. Ct. May 24, 1962); id. Baltimore Daily Record, July 2, 1962, p. 3, cols. 4-5. See also Sobel v. Adams, Civil No. 182-62-M, S.D. Fla., Aug. 1962, pp. 6-8; Brief for the United States as Amicus Curiae, pp. 25-36, Baker v. Carr, 369 U.S. 186 (1962); Bickel, The Great Apportionment Case, New Republic, April 9, 1962, p. 13.

85 See, e.g., WMCA, Inc. v. Simon, 31 U.S.L. WEeK 2121 (S.D.N.Y. June 16, 1962); Sobel v. Adams, supra note 84; Caesar v. Williams, 371 P.2d 241, 248-49 (Idaho 1962). But see McKAY op. cit. supra note 64 , at 8, arguing that the only proper protection of minorities against being "unreasonably disadvantaged" by the majority is the "constitutional protection in bills of rights."

86 Bickel, supra note 84, at 14, quoting from Wechsler, The Political Safeguards of Federalism: The Role of the States in the Composition and Selection of the National Government, 54 CoLum. L. REv. 543 (1954).

87 The objective in drawing such a line, of course, is to prevent this preservation of the "responsiveness to lesser voices" from overshadowing the basic objective of responsiveness to the population as a whole. Deviation from "practical equality" of representation cannot reach the point where the legislative voice preserved to insure representation of the views of minority interest is, in fact, more powerful than that of the majority. The egalitarian philosophy of the "one man-one vote" concept is then not merely tempered, but destroyed. 
suggest that the outer limits of the permissible inequality should be determined to some extent by the nature of the considerations relied upon to justify the inequality. ${ }^{88}$ Thus, for example, the desire to provide each municipality a representative in one house might justify some small departures from per capita equality but not a "substantial departure" because, inter alia, the justification for municipal representation has lost much of its force since local governments have lost their "historic separation and importance" as governmental entities. ${ }^{89}$ Contrary to this approach, the courts have tended to set the outer limits of numerical inequality in the abstract without regard to the particular considerations which might be relied upon as a justification for such inequality. They have looked at the problem from the viewpoint of how much equality of representation there must be despite any "rational justification" rather than to what extent inequality may be warranted by $a$ particular type of justification. ${ }^{90}$

In drawing the outer limit in this manner, the courts have, as one might expect, varied considerably in their conclusions. Some courts have suggested that so long as apportionment in one house of a bicameral legislature is based primarily upon numerical equality of representation, the other house may be apportioned on any "rational" basis. ${ }^{91}$ One court, ${ }^{92}$ while accepting this suggestion generally, has imposed upon it an interesting condition. In the lower house, which was, according to the state constitution, to be apportioned upon the basis of population, the court refused to accept even so slight a departure from that basis as the assignment of a representative to counties and groups of counties which had only two-thirds of the population ideally to be represented by each legislator, although the two-thirds principle was considered a "rational" means of protecting the interests of sparsely set-

\footnotetext{
88 Brief for the United States as Amicus Curiae, pp. 30-35, Baker v. Carr, 369 U.S. 186 (1962).

88 Id. at 33. Protection of rural minorities, on the other hand, might permit a greater departure. See Id. at 29-30.

90 See, e.g., Sims v. Frink, Civil No. 1744-N, M.D. Ala., July 21, 1962, pp. 11-13; Baker v. Carr, 206 F. Supp. 341, 349 (M.D. Tenn. 1962; Toombs v. Fortson, 205 F. Supp. 248, 257 (N.D. Ga. 1962).

91 See, e.g., Toombs v. Fortson, supra note 90, at 257; Maryland Comm. for Fair Representation v. Tawes, Baltimore Daily Record, July 2, 1962, p. 3, col. 3, Anne Arundel County Cir. Ct., aff'd, 182 A.2d 877 (Md. 1962).

92 Baker v. Carr, 206 F. Supp. 341 (M.D. Tenn. 1962).
} 
tled areas and therefore might be used in the upper house. ${ }^{93}$ Still another court suggested that neither house must be strictly apportioned upon a population basis, but "representation according to population to some extent must be required in both Houses if invidious discrimination in the legislative systems as a whole is to be avoided." 94 Here, the scope of "some extent" was not defined but it would appear to require apportionment based essentially upon population with a possible deviation resulting from a provision distributing perhaps one-third of the seats in both houses upon a rational non-population basis. ${ }^{95}$ Along similar lines, the suggestion has also been made that one house must be apportioned entirely on population while the other must be apportioned substantially on population..$^{98}$ Finally, one court's opinion, while not dealing with both legislative houses, suggested that considerations such as the representation of political units or regional interests might be used to justify departures from a population standard in both houses, but that such departures could not produce more than a two-to-one disparity in individual voting power ${ }^{97}$ - the same standard applied by the Michigan court under a "practical equality" of representation test. ${ }^{98}$

More revealing than the results the courts have reached, how-

93 Id. at 345-50.

94 Sims v. Frink, Civil No. 1744-N, M.D. Ala., July 21, 1962, p. 13. The Sims court also seemed willing to accept a bicameral legislature in which one house was apportioned solely on population and the other house was apportioned on another "rational" basis. Ibid.

95 The court appeared to accept a lower house in which sixty-seven of the 106 seats were reserved on a one-per-county basis and the remainder were apportioned according to population. Id. at 1I-13. See also N.Y. Times, July 22, 1962, p. 1, col. 2; p. 46, col. 5 . But, with so great a departure from per capita equality of representation in the lower house, it found unacceptable an upper house apportioned completely on a non-population basis.

96 See Brief for the United States as Amicus Curiac, p. 30, Baker v. Carr, 369 U.S. 186 (1962), suggesting that, while it may be permissible to apportion one house of the legislature so that rural areas with $30 \%$ of the population control $51 \%$ of the seats, the other house would have to be apportioned strictly on a population basis. See also Cox, supra note 76, at 712 .

97 Sweeney v. Notte, 183 A.2d 296 (R.I. 1962). The court states that any disparity of four-to-one or greater in numerical representation constitutes "invidious discrimination." In establishing guidelines for legislative action, however, it suggested an apportionment which would limit disparity to a two-to-one ratio. Id. at 301. While the decision was limited to apportionment of the lower house, the court appeared somewhat skeptical of the suggestion that the apportionment of the upper house might be "grossly discriminatory" so long as the lower house were apportioned "so as to conform reasonably to population." Id. at 302 .

98 See text at notes 50-54 supra. 
ever, is the manner in which they have reached them. Many courts have justified their conclusions by little more than a reference to the phrase "invidious discrimination," as though that phrase had in itself some intrinsic quantitative meaning. ${ }^{90}$ Typical is the following comment by the Supreme Court of Rhode Island:

"The attorney general contends, and petitioners concede, that apportionment along geographical, county, municipal or urban versus rural lines does not necessarily constitute a denial of equal protection if the rationale of such methods can be justified. We are in full accord with such contention, but it is equally true that historical recourse to such apportionment formulae cannot be justified if it results in invidious discrimination. The dilution of the vote of a majority of electors to one fourth of that enjoyed by others is, in our opinion, so unjust as to be invidiously discriminatory." 100

Why the four-to-one ratio was suggested rather than a five-to-one or three-to-one ratio remains hidden within the judgment of the court. ${ }^{101}$

Other, more venturesome courts have attempted to spell out the justification for the particular outer limit of numerical inequality in representation which they have imposed..$^{102}$ Even here, however, some confusion seems to exist. Thus, one court has stated that the constitutionality of an apportionment scheme must be determined by a consideration of the following factors: (1) whether the state policy is "rational," (2) whether the apportionment system is "arbitrary," (3) whether the "present complexion of the legislature has a historical basis in our political institutions, either federal or state," and (4) whether there lies within the state electorate any remedy for gross inequalities of representation such as

\footnotetext{
09 See, e.g., Maryland Comm. for Fair Representation v. Tawes, 30 U.S.L. WEEK 2587 (Anne Arundel County Cir. Ct. May 24, 1962); Levitt v. Attorney Gen., 179 A.2d 286, 291, petition for rehearing denied, 180 A.2d 827 (N.H. 1962) (using "rational basis" the way other courts used "invidious discrimination"); Sweeney v. Notte, 183 A.2d 296, 301 (R.I. 1962).

100 Sweeney v. Notte, supra note 99 , at $\$ 301$.

101 Actually the court later suggested a system of apportionment which would produce no more than a two-to-one ratio. See note 97 supra.

102 See Sims v. Frink, Civil No. 1744-N, M.D. Ala., July 21, 1962, p. 8; Toombs v. Fortson, 205 F. Supp. 248, 254-58 (N.D. Ga. 1962). See also Sanders v. Gray, 203 F. Supp. 158 (N.D. Ga. 1962).
} 
a provision for initiative and referendum. ${ }^{103}$ The distinction between the first and second factors is not altogether clear. They would appear to be merely opposite sides of the same coin-if the state lacks a "rational basis" for apportionment then the resulting system should be arbitrary and vice versa. Moreover, stated either way, neither factor is very helpful in itself without some explanation of what constitutes "arbitrariness" or "rationality." The third and fourth factors, one would gather, are aimed at providing this explanation. With respect to them, the question may be asked as to whether the availability of political means to alter legislative apportionment goes to the issue of the constitutionality of the apportionment or the issue of whether a court should grant relief even if a denial of equal protection is shown. Mr. Justice Clark, who relied upon the unavailability of legal remedies in his separate opinion in the Baker case, seems to treat it as a factor going only to the availability of relief. ${ }^{104}$

\section{Rationality Without More}

The judicial discussions of what considerations are relevant in determining the maximum inequality of representation permissible under a "rational deviations" standard point up what is probably the basic flaw in that standard, and for that matter, in a "practical equality" standard as well. Why must legislative apportionment be based predominantly on population, if not solely on population, in order to meet the requirements of the fourteenth amendment? On what grounds have courts assumed that inequalities in numerical representation based on otherwise "rational" factors constitute "invidious discrimination" when so great as to subordinate population as the controlling basis for apportionment? Why should not inequalities in numerical representation be justified as based on a "rational" classification even where population is given no greater weight in the apportionment scheme than the several other factors mentioned by the Solicitor General?

Any attempt to answer these questions must begin with an analysis of the process by which courts determine the validity of

103 Toombs v. Fortson, supra note 102, at 254-56.

104 See Baker v. Carr, 369 U.S, 186, 251-52 (1962) (concurring opinion of Justice Clark). Compare Brief for the United States as Amicus Curiae, pp. 32-33, Baker v. Carr, 369 U.S. 186 (1962). 
legislative discrimination under the equal protection clause. Certainly the customary judicial definition of equal protection in terms of "rational classification" and "invidious discrimination"both hardly self-defining phrases- reveals little of this process. ${ }^{105}$ Somewhat more descriptive is the suggestion of the majority opinion in Baker that the equal protection provision is aimed at discrimination which "reflects no policy, but simply arbitrary and capricious action." 108 Though difficult at times, one can usually determine whether legislative discrimination is founded upon a "policy," a product of reasoning as opposed to whim and caprice, by the presence in the discrimination of a definite program of variant legislative treatment of persons or groups of persons according to some relevant difference in their composition. Unfortunately, however, the definition of equal protection suggested by Baker is only half complete. Discrimination may be based upon a reasoned policy, yet be considered "irrational" and therefore unconstitutional. For example, assume that a state legislature composed entirely of octogenarians passes a law prohibiting citizens under eighty years of age from running for public office because such candidates would be able to campaign with a youthful vigor which the incumbents could not match. Surely the discrimination in such a hypothetical case would be predicated upon a reasoned policy and surely also it would not be constitutionally valid. For the legislature must not only have a reason for discriminating, but it must be, as Justice Brandeis once stated, a reason "which an informed, intelligent, just-minded, civilized man could rationally favor." 107 Of course, what will so impress the civilized man will

105 But see Toombs v. Fortson, 205 F. Supp. 248, 254 n.4 (N.D. Ga. 1962), which cites the dictionary definition of "arbitrary" in support of its conclusion that the Georgia apportionment fit that category; Sanders v. Gray, 203 F. Supp. 158, 168 n.9 (N.D. Ga. 1962) (doing the same with the dictionary definition of "invidious"). Actually, while the phrases are used interchangeably by the courts, they do have different connotations. The term "invidious" suggests more of an insertion of the personal viewpoint of the decisionmaker. The phrase "invidious discrimination" has been popularized in large part by Justice Douglas. See, e.g., Baker v. Carr, 369 U.S. 186, 244, 245 (1962) (concurring opinion); Williamson v. Lee Optical, Inc., 348 U.S. 483,489 (1955); South v. Peters, 339 U.S. 276 , 278, 281 (1950); Skinner v. Oklahoma ex rel. Williamson, 816 U.S. 535, 541 (1942).

106369 U.S. at 226. See text at note 11 supra.

107 Quaker City Cab Co. v. Pennsylvania, 277 U.S. 389, 406 (1928) (dissenting opinion). This opinion contains probably the most complete judicial description of the application of the equal protection clause: "[T] he equality clause requires merely that the classification shall be reasonable. We call that action reasonable which an informed, intelligent, just-minded, civilized man could rationally favor. In passing upon legislation assailed 
depend in the end upon the values of his civilization. While the range of "rationality" is broad, it necessarily is limited by the basic value system within which it operates. Where the policy advanced to justify a discrimination violates a basic tenet of that system, it will necessarily be rejected as "irrational."108 Thus, when the hypothetical legislators discriminated against younger men solely to preserve their own positions, the use of public power for a private purpose would be contrary to a most fundamental postulate of government in our democratic society, and the discrimination therefore would be considered unconscionably arbitrary. Using the more conventional terminology of equal protection, a court might find that the basis for the discrimination here does not bear a "real and substantial relation to the subject of the legislation," 109 or more accurately, that while the discrimination is

under the equality clause we have declared that the classification must rest upon a difference which is real, as distinguished from one which is seeming, specious, or fanciful, so that all actually situated similarly will be treated alike; that the object of the classification must be the accomplishment of a purpose or the promotion of a policy, which is within the permissible functions of the State; and that the difference must bear 2 relation to the object of the legislation which is substantial, as distinguished from one which is speculative, remote or negligible." Id. at 406.

108 See ibid. See also Sanders v. Gray, 203 F. Supp. 158, 170 (N.D. Ga. 1962). This definition of "rationality" of classification seems equally applicable to discriminations interfering with economic or personal liberties. Thus, the Court has verbalized the equal protection test in the same manner in cases involving both types of liberties, and has relied upon decisions involving economic restrictions in opinions dealing with personal restrictions, and vice versa. Compare Skinner v. Oklahoma ex rel. Williamson, 316 U.S. 535, 540-41 (1942), with Williamson v. Lee Optical, Inc., 348 U.S. 483, 489 (1955). However, there probably are more fundamental values relating to personal liberties with which the policy justifications for a particular discrimination must be consistent; hence, inequalities in that area are more likely to be held unconstitutional.

109 Quaker City Cab Co. v. Pennsylvania, 277 U.S. 389, 402 (1928). This phraseology is derived from one of the most frequently cited "rules" of the equal protection clause: a classification to be legal must "rest upon distinctions having a fair and substantial relation to the object sought to be accomplished by the legislation." Atchison, T. \& S.F. Ry. v. Vosburg, 238 U.S. 56, 59 (1915). See Allied Stores, Inc. v. Bowers, 358 U.S. 522, 527 (1959) (collecting cases). By insisting that the classification be explainable in terms of the policy behind the legislation this rule would seem to be aimed primarily at ensuring that the classification does not represent a capricious drawing of statutory lines without any particular reason for doing so. As applied, however, its function is much broader. In determining whether a particular basis for classification is related to a statutory policy, the Court refuses to consider any possible legislative purposes which, though based on reason, would be contrary to the basic principles which limit the scope of governmental power. See, e.g., Wheeling Steel Corp. v. Glander, 337 U.S. 562 (1949), and Southern Ry. v. Greene, 216 U.S. 400 (1909), as explained in Allied Stores, Inc. v. Bowers, supra at 530 (concurring opinion). See also Griffin v. Illinois, 351 U.S. 12 (1956); Oyama v. California, 382 U.S. 633 (1948). It is only in rare cases, however, that the Court gives explicit recognition to the fact that this approach has been adopted. See note 110 infra. 
based upon a reasoned classification, "the object of the classification ... is the promotion of a policy which is [not] within the permissible functions of the State." 110 If, on the other hand, the same type of discrimination were justified on a policy consistent with our fundamental values, it would be upheld as based upon a "rational classification," even if such policy were contrary to lesser, more transitory values subscribed to by the contemporary community. ${ }^{111}$ Thus, if the hypothetical legislature required that all candidates for office be at least twenty-one years old so as to insure a minimum degree of experience and maturity in legislators, the discrimination against minors would be upheld as based upon "rational" grounds even though public opinion favors equal opportunity for all citizens irrespective of their age and maturity. What makes the discrimination reasonable in this case and arbitrary in the other is not the distinction between a policy justification and no policy justification, but between justifications consistent and inconsistent with those fundamental conceptions of the object of government which our society has continuously accepted.

The application of this approach in determining the rationality of the alleged justifications for discrimination requires some deference to the judgment of the legislature, which by the very nature of its position should be appreciative of our fundamental values. ${ }^{112}$ Even more significant is the place of history in determining "rationality"; for the continued survival of a practice over a lengthy period of time is some evidence in itself that the practice is not contrary to our basic values. ${ }^{113}$ Finally, the Constitution,

110 Quaker City Cab Co. v. Pennsylvania, 277 U.S. 389, 406 (1928) (dissenting opinion). See also Watson v. State Comptroller, 254 U.S. 122, 124-25 (1920); Truax v. Raich, 239 U.S. 33, 41-42 (1915). Although this determination is discussed in the context of applying the equal protection clause, it is, perhaps, more basically an aspect of due process rather than equal protection. See Bolling v. Sharpe, 347 U.S. 497, 499-500 (1954); Rast v. Van Deman \& Lewis, 240 U.S. 342, 358 (1916). However, in view of the overlapping coverage of the two clauses, this distinction is without significance for our purposes here. See Bolling v. Sharpe, supra.

111 See, e.g., McGowan v. Maryland, 366 U.S. 420, 425-28 (1961).

112 See generally Missouri, K. \& T. Ry. v. May, 194 U.S. 267, 270 (1904).

113 See Toombs v. Fortson, 205 F. Supp. 248 (N.D. Ga. 1962); Sanders v. Gray, 203 F. Supp. 158, 169 (N.D. Ga. 1962). See generally Kotch v. Board of River Boat Pilot Comm'rs, 330 U.S. 552 (1947). Of course, this refers only to the historical practice which has survived as a result of general acceptance by the public. Moreover, the historical acceptance of a practice, while highly relevant, is not itself determinative of constitutional validity. Other considerations may indicate that a policy is contrary 
as the guiding framework of our government, serves in itself as the most significant indicator of our basic values, particularly insofar as the government and its relation to the individual is concerned.

In the light of this analysis of the process of determining "rationality," can it be said that apportionment based on factors other than numerically equal representation of the population violates the equal protection guarantee of the fourteenth amendment? Certainly representation according to political subdivisions, geographical regions, or functional divisions in the population, both economic and demographic, is generally the product of a reasoned policy based upon actual differences in the interests represented..$^{114}$ But can it be maintained that such representation is contrary to some fundamental principle inherent in our governmental system? To sustain this position, one must discard much of our national history, not to mention our English heritage. ${ }^{115}$ We have had more than a few state governments in which population was a minor or completely absent factor in determining representation..$^{110}$ Ownership of real property was once thought to be so important that it was the primary basis for allocating representation in some states. ${ }^{117}$ Yet, in reply, it may be argued

to our basic values even though it has had some widespread acceptance over a long period of history. Cf. Brown v. Board of Education, 347 U.S. 483 (1954).

114 See DeGrazia, Public and Republic 205-07, 241-58 (1951) (outlining such policies and their historical development); DeGrazia, General Theory of Apportionment, 17 LAW \& CONTEMP. PROB. 256-62 (1952). Accordingly these factors are entitled to be characterized as "reasoned" even though they may still be "arbitrary" in terms of the equal protection clause because the policy "justifying" their use contradicts some fundamental value of our political system.

115 On the English attitude toward representation on a population basis, see the material collected by Justice Frankfurter in Baker v. Carr, 369 U.S. 186, 302.04 (1962) (dissenting opinion). See also DeGrazia, General Theory of Apportionment, 17 LAW \& CONTEMP. PROB. 256, 258-59 (1952), describing generally the historical use of criteria other than population in apportionment.

116 Many early colonial legislatures were apportioned strictly on a geographical basis. Baker v. Carr, 369 U.S. 186, 309-10 (1962). This tradition has been carried on in many states. In Maryland, for example, population did not become a factor in apportioning either house until 1851. Maryland Comm. for Fair Representation v. Tawes, 180 A.2d 656, 672 (Md. 1962) (dissenting opinion). And even after population was considered in the apportionment scheme, it often was a comparatively minor factor. See, e.g., Sanders v. Gray, 203 F. Supp. 158, 161-63 (N.D. Ga. 1962) (describing the history of the Georgia county unit system). See also Scholle v. Hare, 360 Mich. 1, 93-100, 104 N.W.2d $63(1960)$.

117 See, e.g., Luther v. Borden, 48 U.S. (7 How.) 1 (1849). See also the comment of DeGrazia, supra note 115, at 259: "In the American Constitutional Convention of 1787, 
that our system of values with respect to the individual and his relationship to the government should not be determined in the light of archaic and often abandoned state practices. Rather the "rationality" of non-population bases for apportionment should be judged against the values suggested by the objectives of our revolution and, more significantly, of the constitutional "revolution" subsequent to the Civil War which produced the fourteenth, ${ }^{118}$ fifteenth, seventeenth and nineteenth amendments.

The basic dilemma presented by this argument lies in the nature of the inquiry itself. Regardless of whether one concludes that numerical equality of representation is or is not one of the few fundamental values of our system, that determination must revolve about an interpretation of the leading constitutional evidence of our values with respect to the form of state governments, article IV, section 4, of the Constitution, which guarantees to the states a "republican" form of government. ${ }^{119}$ It is in the light of the requirement of a "republican" form of government that the essentiality of per capita equality of representation must be judged. If reasoned, non-population bases for apportioning state legislatures are considered "irrational," it is only because the concept of republican form of government, possibly as supplemented by historical practice and other parts of the Constitution, requires a representative democracy based upon complete political equality of the individual. ${ }^{120}$ That an interpretation of the constitutional meaning of a "republican form of government" is the key to a position requiring primary emphasis upon numerical equality of representation is clearly illustrated by the fact that most of the courts which have attempted to justify that position have emphasized that it was an attribute of that guarantee. ${ }^{121}$ The argument

consideration was given to the possibility of allocating representation according to the taxes paid by a state, but, partly because tax-paying areas were believed to coincide with areas of high population density, population was chosen as the basis for representation."

118 The reference here is to the second section of the fourteenth amendment rather than the more well-known first section. See generally MCKAY, REAPPORTIONMENT AND THE FEDERAL ANALOGY 6-7 (1962).

110 "The United States shall guarantee to every state in this union a republican form of government, and shall protect each of them against invasion. . . U. S. CoNST. art. IV, \& 4.

120 See generally Ragland v. Anderson, 125 Ky 141, 160, 100 S.W. 865, 869 (1907); State ex rel. Harte v. Moorhead, 99 Neb. 527, 536-39, 156 N.W. 1067, 1070-71 (1916); DeGrazia, supra note 115 , at 256-57, 261.

121 See, e.g., text at note 59 supra, quoting from Moss v. Burkhart, Civil No. 9130, 
which they have advanced, although not always clearly, is that a "republican" form of government requires a popular democracy; ${ }^{122}$ that this, in turn, presupposes an equality of the individual and, hence, of his voting power; and that, therefore, legislative representation on bases other than population is inconsistent with our political system, although it may be very reasonable for other, nonrepublican forms of government. It is this argument and only this argument which will justify a standard of "practical equality" of representation or practical equality with some "rational deviations" as the standard for judging the constitutionality of legislative apportionment. The difficulty with the argument is that it must start with an interpretation of the concept of a "republican" form of government, and that, presumably, is not permitted.

The Supreme Court has consistently refused to interpret this clause on the ground that questions involving the interpretation of the "republican form of government" provision are non-justiciable "political" questions. Whether properly or not, the Court has refused in Luther $v$. Borden ${ }^{123}$ and various other decisions ${ }^{124}$ to answer the precise question presented here: what is the nature of our representative democracy in terms of the distribution of power among the populace or, phrased differently, to what degree must the majority control the government through either the legislative representatives or some other governmental device ${ }^{125}$ The major-

D. Okla., June 19, 1962, pp. 5-6; id. at Appendix III; Toombs v. Fortson, 205 F. Supp. 248 (N.D. Ga. 1962), where the court states at 256, "the State statute . . o offends what are found to be fundamental political concepts inherent in a republican form of government ... and ... must be stricken because of discrimination so excessive as to be invidious"; Maryland Comm. for Fair Representation v. Tawes, 30 U.S.L. WEEK 2587 (Anne Arundel County Cir. Ct. May 24, 1962); id., Baltimore Daily Record, July 2, 1962, p. 3, col. 5, aff'd, 182 A.2d 877 (Md. 1962). See also the authorities cited in note 122 infra.

122 See generally In re Duncan, 139 U.S. 449, $461-62$ (1891); Jefferson, Letter to $S$. Kercheval, 10 Writincs of Thomas JefFerson 37, 38-41 (Ford ed. 1899); The Federalist, No. 39, at 245 (Ford ed. 1898) (Madison).

12348 U.S. (7 How.) 1 (1849).

124 See, e.g., Ohio ex rel. Davis v. Hildebrant, 241 U.S. 565 (1916); Marshall v. Dye, 231 U.S. 250 (1913); Pacific States Tel. \& Tel. Co. v. Oregon, 223 U.S. 118 (1912). See also Baker v. Carr, 369 U.S. 186, 223 (1962) (listing and describing the cases which have followed Luther $v$. Borden). But cf. In re Duncan, 139 U.S. 449, 461-62 (1891); Minor v. Happersett, 88 U.S. (21 Wall.) 162 (1874).

125 In Luther v. Borden, 48 U.S. (7 How.) 1 (1849), for example, the question posed was whether the "republican form of government" provision required that a majority of the populace-including non-freeholders, ordinarily not allowed to vote-had an "indubitable, inalienable, and indefeasible right" to adopt a new government when the present government did not suit them. 48 U.S. (7 How.) at 19-20. In Pacific States Tel. 
ity opinion in Baker indicated no willingness to depart from these decisions; to the contrary, it specifically announced continued adherence to them. ${ }^{126}$ Thus, since the use of reasoned, non-population based factors in apportioning a legislature is "irrational" only if contrary to the most fundamental societal values, and since to establish such values one must necessarily rely upon a definition of "republican" form of government, it would seem that requiring a complete or primary emphasis upon numerical equality of representation in legislative apportionment goes beyond the Baker decision, at least insofar as the Court purportedly continues to adhere to its position that a "political" question determination is inherent in an interpretation of this clause. ${ }^{127}$

At this point, the question might be raised as to whether there is anything left to the equal protection clause in the apportionment context. If the basic principle of popular democracy, as required by a "republican" form of government, cannot be used to judge the "rationality" of numerical inequalities in representation resulting from apportionment schemes based upon non-population factors, can any system of apportionment result in the denial of equal protection? For, aside from the concept of a governmental framework which requires equality of individual representation, cannot all major inequalities in per capita voting power be justified as based on factors, such as representation of regional interests or political subdivisions, which constitute "rational" bases for numerical differences in legislative representation? These were essentially the questions asked of the majority by the dissenters in the Baker case. ${ }^{128}$ The Court's answer apparently was that equal protection standards can be applied to apportionment inequalities without consideration of the "republican form of government"

\& Tel. Co. v. Oregon, supra note 124, the question posed was whether the "republican form of government" provision limited the function of legislating solely to the legislature or whether legislation might also be adopted directly by a vote of the majority of the populace, who may not be able to control the legislature. 223 U.S. at 120-25.

128369 U.S. at 226-29. See Bonfield, Baker v. Carr: New Light on the Constitutional Guarantee of Republican Government, 50 CALTF. L. REV. 245, 247 (1962); Katzenbach, Some Reflections on Baker v. Carr, I5 VANd. L. Rev. 829, 831 (1962).

127 See Bonfield, supra note 126, suggesting that Baker might lead the Court to change its mind on the non-justiciability of claims based on the content of the "republican form of government." See also Note, 15 VAND. L. REv. 985, 1004 (1962).

128369 U.S. at 298-99. 
clause and the political philosophy it imposes on our state governments. ${ }^{129}$

Unfortunately, the Court gave no explanation for this answer. If it had given an explanation, it might have been along the following lines. First, the equal protection clause continues to require some principled justification for different treatment of similar groups. Second, even if such a ground is advanced, its "rationality" can be judged against fundamental values of our society other than our basic philosophy of political structure, values which do not require an examination of the relationship of equality in representation to the "republican form of government" clause. Certainly a legislature could not apportion a district so that each of the legislator's homes would constitute a separate election district, with the remainder of the state constituting a single additional district. Discrimination justified solely in terms of the legislators' selfinterest cannot be said to be a "rational" classification, regardless of whether the "republican form of government" clause requires popular democracy with total equality of representation. ${ }^{130}$

Of course, as the nature of this example indicates, the equal protection guarantee has less practical significance under this view than it would under a view which, in the light of some egalitarian philosophy found in the concept of a "republican form of government," would be insistent upon substantial per capita equality of representation as the only "rational" basis for apportioning a legislature.The impact which the equal protection clause will have when divorced from the implications of such a political philosophy will depend upon the degree to which the Court will rely on the presumption of constitutionality that requires it to assume "any state of facts [which] reasonably may be conceived" to justify a statutory discrimination. ${ }^{131}$ At least a few instances of unconstitutional apportionment can be pictured, however, irrespective of the weight placed on that presumption. One such apportionment could be that involved in the Baker case itself.

The apportionment situation in Tennessee presented inequalities of representation, resulting from over fifty years of legislative

129 See 369 U.S. at 226, 228-29.

130 Even the dissenters in Baker apparently would accept this conclusion. Baker v. Carr, 369 U.S. 186, 335-37 (1962) (dissenting opinion of Justice Harlan).

131 See McGowan v. Maryland, 366 U.S. 420,426 (1961), and cases cited therein. 
inaction, which apparently could not readily be justified on any ground. According to Mr. Justice Clark, apportionment of the Tennessee legislature lacked consistency whether allegedly based on population, equal representation of political units, protection of rural or other minority interests, geography, or any other "rational" policy. ${ }^{132}$ In dissent, Mr. Justice Harlan nevertheless insisted that to find no "rational" basis in this legislative apportionment was to ignore the Court's duty to assume any conceivable set of circumstances which might justify the state's existing arrangement. He suggested that the Court assume that what Mr. Justice Clark described as a "crazy quilt" of election districts was actually a "rational" scheme based upon some compromise which balanced various geographical and demographical factors in varying portions. ${ }^{133}$ While Mr. Justice Harlan's suggestion may have merit in other contexts, it is not convincing in the Tennessee situation. The Court should not be required to assume some "rational" formula based on the balancing of various factors where all the circumstances contradict its presence. ${ }^{134}$ The relevant state constitutional provision required reapportionment every ten years solely on the basis of population ${ }^{135}$ - a command which had obviously not been obeyed. ${ }^{136}$ In fact, the last legislative apportionment had occurred in $1901 . .^{137}$

132369 U.S. at 254-57. This conclusion is supported by reference to both Justice Clark's and Justice Harlan's formula for determining the degree of representation of a particular district.

133369 U.S. at $334-35,337-38,345-48$.

134 See Hartford Steam Boiler Inspection \& Ins. Co. v. Harrison, 301 U.S. 459, 462 (1937).

185 TENN. Const. art. II, \& 6.

136 The emphasis placed upon this factor does not constitute acceptance of petitioners' argument in Baker that the state was barred from advancing any "rational" basis for the discrimination because any such justification would be contrary to the Tennessee constitution. While tempting, that approach was properly rejected by Justice Frankfurter as flying in the face of the ruling in Nashville, C. \& S.L. Ry. v. Browning, 310 U.S. $362(1940)$. [See 369 U.S. at 325-27.] There, the Court opinion (by Justice Frankfurter) found that a discrimination in the living law-the law as applied by enforcement agencies-could not be rejected as "invidious" even though the written law of the state forbade such discrimination. In Browning, however, the rational basis for the inequality in the application of the law was self-evident. Furthermore, the discrimination was the product of a systematic pattern of action which produced a constant distribution of the inequality. Browning, therefore, does not preclude reliance upon the contrary direction of state law to show the lack of policy behind discrimination, where, as here, not only is no "rational" basis evident upon the surface of the discrimination, but the means of imposing the discrimination suggests that there never was such a basis.

137 Tens. CODE ANN. \$ई 3-101-107, subsequently amended in 1962, Public Chapter No. 1, Extraordinary session of 1962. See Baker v. Carr, 206 F. Supp. 341, 345-47 (M.D. Tenn. 1962). 
The inequalities in representation in Tennessee were not the product of any affirmative legislative action, but merely the result of natural shifts in population accompanied by legislative inaction for over a half of a century. In such circumstances, to suggest that the Tennessee apportionment was the product of the application of any formula based upon "rational" considerations is to overlook reality. To the contrary, in such a situation one cannot but assume that the only reason for the inequality in representation is the legislature's desire not to "rock the boat"; ${ }^{138}$ and this policy, whether merely a product of natural legislative inertia or a reflective decision to preserve and entrench the incumbent's political power, cannot "rationally" justify discrimination. Under these circumstances, the least that can be asked of the legislature is some affrmative showing that inequalities in representation were based on some reason other than the legislators' personal interests. Thus, if the Tennessee legislature were to reapportion the state along lines incorporating the same inequalities but based upon some "rational" formula, even one resting ninety percent on representing geographical and regional interests and ten percent on population, the discrimination could arguably be justified as a "rational" classification; ${ }^{139}$ but when those inequalities are presented as in the Baker case, with no greater reason evident than the legislature's self-interest, then the discrimination must be considered "invidious."140

138 Contrary to Justice Harlan's suggestion, this conclusion may be reached without undermining the long-accepted rule that a court will not inquire into the personal motives of the legislators. See 369 U.S. at 337; Fletcher v. Peck, 10 U.S. (6 Cranch) 87 (1810). This rule has never prevented the Court from determining the purpose of the legislature as a body in passing legislation, and certainly that purpose may be indicated by the effect of the legislation. See, e.g., Gomillion v. Lightfoot, 964 U.S. 339, 341 (1960); Harxison v. NAACP, 360 U.S. 167, 175 (1959). For a much more complete discussion of the difference between legislative purpose and legislators' motives, see Gomillion v. Lightfoot, 270 F.2d 594, 608-11 (5th Cir. 1959) (dissenting opinion of Judge Brown, whose position was subsequently sustained on appeal), rev'd, 364 U.S. 399 (1960).

139 As a practical matter, it seems unlikely that the same inequalities will be reenacted, even though they may be "justifiable" insofar as the equal protection clause is concerned. In the past, the most serious numerical inequalities in apportionment have been the product of legislative failures to reapportion to accommodate population shifts rather than affirmative statutory provisions apportioning on the basis of non-population considerations. See Hacker, Message on the State of the States, N.Y. Times, July 22, 1962, \& 6 (Magazine), pp. 15, 27, col. 4; Lewis, Legislative Apportionment and the Federal Courts, 71 HaRv. L. REv. 1057, 1060 (1958).

140 Quite a few states may fall into this category. Twenty-seven have not reapportioned for a quarter-century or more, although most of them had at least one house which was to be apportioned on the basis of population. Lewis, Decision on Reappor- 
When, unlike Tennessee, the legislature-or better yet, the electorate-has taken affirmative action on apportionment, then Mr. Justice Harlan's warning must be kept in mind. The courts cannot expect that inequalities in representation will be clearly explained by some precise, mathematical formula which allocates specific weight to the various factors considered in the apportionment. ${ }^{141}$ "No finicky or exact conformity to abstract correlation is required of legislation" by the equal protection clause. ${ }^{142}$ This principle may have been overlooked by the Supreme Court of Michigan in deciding the Scholle case. The majority opinions there found that the apportionment of the state senatorial seats was made "without any discernible or conceivable basis." 143 The rationale offered in support of that conclusion is interesting to note. ${ }^{144}$ Since the senatorial election districts contained vast differences in population and area, neither of these factors, according to the argument, could be the basis of the apportionment. Similarly, since the districts were composed of from ten counties to less than one county, certainly representation of political units could not be the basis of the apportionment. Finally, since rural populations of the same size represent different portions of the total electorate in their respective districts, the apportionment could not have been based on a rural-urban distinction. ${ }^{145}$ Therefore, the rationale concluded,

tionment Points Up Urban-Rural Struggle, N.Y. Times, April 1, 1962, \& 4, p. 3, col. 2; Lewis, supra note 139, at 1060-61. In such instances the natural shifts in population usually will have produced a present scheme of apportionment without any "rational" pattern. Of course, this may not always be the case. Possibly there may have been few shifts in population in a particular state. Also, the shifts may have been so orderly that the present apportionment follows a clear pattern based in part on non-population factors, for example, balance between farm and urban areas. In most cases, however, the situation will be the same as that in Tennessee.

111 Usually, of course, the legislature never gives any precise weight to the factors it considers relevant in apportionment. Politics-and this includes legislative apportionment-is, after all, the art of compromise. The legislature is more likely to agree on a general priority of factors than on a precise mathematical formula. There are exceptions, however. See, e.g., PRoposed MICH. CONST. art. IV, \$§ 2-6 (1962).

142 McGowan v. Maryland, 366 U.S. 420, 524 (1961) (concurring opinion).

143 See 367 Mich. at $242-43,116$ N.W.2d at 381 (concurring opinion of Justice Souris).

14 The opinion cited in note 143 supra contained no exposition of the rationale uscd to support its conclusion. However, Justice Souris did cite the early opinion of Justice Smith which included a detailed argument in support of the majority position. See Scholle v. Hare, 360 Mich. 1, 42, 51-56, 104 N.W.2d 63, 84, 89.91 (1960). Perhaps the clearest articulation of this rationale, however, is the oral argument of the Attorney General of Michigan on behalf of the petitioners. See mimeographed reprint of Attorney General's oral argument at pp. 4-5.

146 Even accepting the general approach of this rationale, comparison of the voting 
the apportionment must lack any reasoned basis. ${ }^{146}$ Such an analysis is much too inflexible for the application of a constitutional provision which is supposed to give the state extremely broad discretion. Equal protection does not require the "logical tidiness"147 for which the Michigan court was apparently looking.

The same opinion which concluded that the Michigan apportionment had no conceivable basis also acknowledged that the result of the apportionment "gives the more sparsely populated rural areas of the state a specific check upon the concentrated political power of the densely populated industrial urban center."148 Why couldn't this result of the apportionment be its basis? It was shown that the apportionment had been presented to the electorate as aimed precisely at achieving this result of giving the rural interests a "check" upon the political influence of the large metropolitan counties. ${ }^{149}$ Might it not be maintained that the Michigan senatorial apportionment was based on a general plan in which population was a secondary factor, subordinated to the primary objective of giving the sparsely populated counties sufficient weight within their senatorial district so as to have a substantial voice in the election of its representative? Thus, the suggestion was made that the apportionment of the thirty-four senate seats was generally based on population, provided, as often was the case, that the resulting districts would not be so large that a sparsely settled county would

strength of equal rural populations in different districts is not the proper test for determining whether an apportionment scheme is designed to grant the rural minority political security against the urban majority. Instead, the court should look to whether the districts with higher percentage of rural population generally have less people over-all. On this basis, the figures in Michigan would be more consistent with a ruralurban division. See 360 Mich. at 55 n.17, 104 N.W.2d at 91 n.17.

146 This approach is similar to that employed by the lower court in Baker v. Carr, 206 F. Supp. 341 (M.D. Tenn. 1962).

147 McGowan v. Maryland, 366 U.S. 420, 524 (1961) (concurring opinion).

148367 Mich. at 286, 116 N.W.2d at 378-79.

149 Defendant's Answer to Plaintiff's Supplemental and Reply Brief, pp. 53, 55, 59, Scholle v. Hare, 360 Mich. 1, 104 N.W.2d 63 (1960), rev'd on rehearing, 367 Mich. 176, 116 N.W. 350 (1962). The present Michigan apportionment provisions were adopted at a general election in 1952. These provisions won out over another proposal on the ballot which would have apportioned both houses of the legislature on a population basis. The proponents of the victorious proposal clearly stated that its objective was to prevent the heavily populated areas from controlling the upper as well as the lower houses. This was commonly referred to as the "balanced legislature" plan. Election statements explaining the objectives of the "balanced legislature" plan were presented to the court through reference to various newspaper articles. 
contribute only a small portion of the district's total electorate. ${ }^{150}$ And, in addition to this proviso, there might be found still a further exception to protect certain regional interests, such as that of the state's northern peninsula. Whether or not the Michigan apportionment might reasonably be said to follow such a general plan involves an analysis of geographical, demographical, and historical facts which are beyond the scope of this discussion. The point is that the Michigan court might well have kept its collective mind open to the possibility of an apportionment scheme as suggested above, rather than closed to everything except some mathematically precise formula. It should have been aware, as a federal district court has recently noted, that apportionment may reasonably be based on "factors adapted to [all] the needs of the state ... constituted as it is of urban, suburban and rural areas, with congestion of population in one spot, with areas of lesser intensity in other locations and with sparsely settled spaces more remote from the centers of population." 151

Of course, under the analysis suggested, once a court can reasonably conceive a general plan of apportionment based on "rational" factors, its tasks under the equal protection clause should be at an end. It should not, as in the Scholle decision, reject all bases for apportionment schemes other than population as arbitrary and therefore insist upon "practical equality" of representation. Neither should it, though most lower courts have done so, permit the use of factors other than population only insofar as population is still retained as the predominant factor. Both of these approaches can be justified only on the basis of a fundamental political value in our society which demands total equality of representation, and, as already noted, sustaining the presence of such a fundamental concept necessarily involves the interpretation of the "republican form of government" guaranteed to the states under article IV, section 4. Unless the Court is to reverse its position in Luther v. Borden and the other cases dealing with that provision, the lower courts must be satisfied with the more limited function in these cases which is here suggested. ${ }^{152}$ They must, as one

\footnotetext{
150 Sec Supplemental Brief of Intervening Defendants, Brief of C. R. Coleman as Amicus Curiae, Scholle v. Hare, 367 Mich. 176, 116 N.W.2d 350 (1962). 161 WMCA, Inc. v. Simon, 31 U.S.L. WEEK 2121 (S.D.N.Y. June 16, 1962). 152 However, while the judicial function under this analysis is considerably nar-
} 
lower court has recently done, accept numerical inequality in representation where apportionment is based not only partially, but even predominantly on reasoned factors other than population. ${ }^{153}$

Finally, one further point should be mentioned. Regardless of whether the Court adopts the more limited equal protection standard suggested here, a standard of "practical equality," or a standard of practical equality with certain "rational deviations," the choice hopefully should be made during the present term. The sooner the legal uncertainty over the applicable standard in apportionment cases is ended, the sooner the judges' role with respect to legislative apportionment-whether it is narrow or broad-will become fully effective. When the majority in Baker carefully avoided providing any specific guidelines as to what constituted unconstitutional apportionment, it obviously was hopeful that its holding on the issue of justiciability would be all that was needed to spur the state legislatures into reapportioning, possibly along lines much more egalitarian than required by the equal protection guarantee. ${ }^{154}$ This hope has not materialized. Most legislatures, even those where the contested apportionment is clearly invalid under any view of equal protection, have been unable, or at least unwilling, to achieve any sort of reapportionment without a lower court decision holding the present state apportionment invalid. ${ }^{155}$ Moreover, even then some legislatures have adopted the policy of making the minimum num-

rower than that suggested by many commentators, it still may have considerable practical significance. See note 140 supra.

163 In Sobel v. Adams, Givil No. 186-62-M, S.D. Fla., Aug. 1962, the court accepted as "rational" a proposed apportionment in which representation of political units was the primary factor. The senate would consist of forty-six members. Each of the twentyfour most populous counties would receive one senator, and the remaining forty-three counties would be divided into twenty-two districts of two or three counties apiece which would elect the other twenty-two senators. The house of representatives would consist of 135 members. Each of the sixty-six counties would be reserved one seat, and the remaining seats would be distributed essentially on a population basis. See also WMCA, Inc. v. Simon, 31 U.S.L. WEEK 2121 (S.D.N.Y. June 16, 1962).

Justice Clark's opinion also indicates that an apportionment based on non-population factors would be constitutionally valid. Thus, Justice Clark characterized the Georgia county unit system, challenged in South v. Peters, 339 U.S. 276 (1950), as based upon "some rational policy." See 369 U.S. at 253 \& n.4, 256 \& n.8. The county unit system, as described by Justice Clark, was "based ... on a consistent combination of political units and population, giving six unit votes to the eight most populous counties, four unit votes to the 30 counties next in population, and two unit votes to each of the remaining counties." Id. at 253 n.4.

154 See Baker v. Carr, 369 U.S. 186, 250 n.5, 269, 339 (1962) (concurring and dissenting opinions); Brief for the United States as Amicus Curiae, pp. 70-73, Baker v. Carr, 369 U.S. 186 (1962).

155 As of October, only one state, Virginia, had apportioned its legislature since 
ber of changes necessary to present a bare façade of compliance with the lower court's order, even though it is expected that such changes may not be sufficient to meet that court's view of equal protection. ${ }^{156}$ This legislative reticence is attributable in part to an unwillingness to make any significant changes until the meaning of "invidious discrimination" in apportionment is clearly defined by the courts. ${ }^{187}$ Whether this is a proper excuse for inaction or not, the fact remains that the absence of clear standards approved by the Supreme Court serves as an open invitation-usually accepted-to legislative refusals to seriously reconsider apportionment either on their own initiative or in response to lower court decisions.

The legislatures' reluctance to act has not been the only undesirable by-product of the absence of a definitive interpretation by the Supreme Court of the equal protection clause as it applies to state legislative apportionment. In the light of the limited holding in the Baker case, lower courts, including an elected judiciary in many states, ${ }^{158}$ have been left almost entirely on their own in determining when numerical inequalities in apportionment constitute "invidious discrimination." Elected state judges in particu-

the Baker decision without the spur of a court decision. N.Y. Times, Oct. 22, 1962, p. 71, cols. 1-5. See 51 National Crvic REv. 441 (1962). Ten states have suggested constitutional amendments, but most of these reflect the pressure of judicial decisions. And while other states are considering reapportionment proposals, it seems unlikely that many basic changes will be made until a court so orders. See N.Y. Times, Aug. 6, 1962, p. 23, col. 1; U.S. News \& World Report, April 9, 1962, p. 53. But see N.Y. Times, Aug. 28, 1962, p. 18, col. 8 .

156 See N.Y. Times, Sept. 6, 1962, p. 33, cols. 4, 6; July 4, 1962, p. 9, col. 1; June 1, 1962, p. 1, col. 8; May 27, 1962, p. 57, col. 1; N.Y. Times, July 12, 1962, p. 21, col. 1. Thus, statutes passed in response to court orders were held invalid in Tennessee and Alabama. See Sims v. Frink, Civil No. 1744-N, M.D. Ala., July 21, 1962; Baker v. Carr, 206 F. Supp. 341 (M.D. Tenn. 1962). The Alabama provision, for example, would not have made any changes until 1966. See N.Y. Times, July 22, 1962, p. 1, col. 2; p. 46, col. 5.

157 Sce, e.g., N.Y. Times, July 2, 1962, p. 30, col. I; June 11, 1962, p. 1, col. 4; p. 26, col. 5; id., cols. 1-4. See also N.Y. Times, May 14, 1962, p. 28, col. 2; June 22, 1962, p. 24 , col. 2 , in reply to this position. In Wisconsin, the combination of a legislature and a governor of different political parties produced a stalemate which neither was willing to break in the absence of a direct court order. See N.Y. Times, July 21, 1962, p. 19, col. 1; July 18, 1962, p. 15, col. 4; July 12, 1962, p. 21, col. 1. The court order never came, however, as the pending suit was dismissed upon the recommendation of a special master. Wisconsin v. Zimmerman, Civil No. 3540, W.D. Wis., Aug. 14, 1962.

158 Approximately one-half of the apportionment suits filed subsequent to Baker have been in state courts. See N.Y. Times, Aug. 6, p. 23, col. 1; Reapportionment Efforts at High Pitch, 51 Nattonal Crvic Rev. 441 (1962); Lewis, Reapportionment Is Gaining Momentum, N.Y. Times, June 17, 1962, § 34, p. 8, col. 1 . 
lar have thus been placed in an unnecessarily delicate political position by the wide range of standards they may adopt without directly contradicting the majority opinion in Baker. ${ }^{150}$ Almost any decision they make will be subjected to charges of political partisanship which could not be so readily raised if the courts' choices of standards were clearly controlled by precedent. ${ }^{100}$ The unfortunate result may be direct judicial entry into the arena of political debate, as was the case in Scholle. There the various opinions were sprinkled with injudicious comments directed at political opponents, ${ }^{161}$ including a scarcely-veiled warning that the majority opinion might go by the wayside if the "wrong" judges were chosen in the upcoming election. ${ }^{12}$ Hopefully, when the dust settles and the Court has spelled out the applicable standards, the restrictions of precedent will force injudicious judges to return to the law and will spur legislatures to appropriate action to eliminate arbitrariness in legislative apportionments.

150 Cf. N.Y. Times, June 12, 1962, p. 23, col. 3. The state courts' position has not been made any easier by statements of state legal officers that the law is clearly one way or another. In both Michigan and Wisconsin, the state Attorney General argued against the validity of the state law. N.Y. Times, July 26, 1962, p. 24, col. 8; July 10, 1962, p. 23, col. 6; June 20, 1962, p. 20, col. 4; Supplemental Brief and Appendix of Defendant Hare, pp. 1-3, Scholle v. Hare, 367 Mich. 176, 116 N.W.2d 350 (1962). The position of the Attorney General in Michigan was that the unconstitutionality of the Michigan constitution was so clear that his oath to support the federal constitution prohibited him from defending the state law.

160 There are indications that criticisms of state court decisions in cases involving legislative apportionment would be considerably more restrained if responsibility for the decision might be attributed to the precedent of a Supreme Court decision. Sec, e.g., the criticism of the Scholle decision in the Detroit News, July 19, 1962, p. 1, col. 5; p. 11, cols. 1-2. Of course, even then, the state courts would still be "on their own" when it came to prescribing the form of judicial relief from unconstitutional apportionment. See id. at p. 19, cols. 1-2.

101 Thus, a substantial portion of Justice Kavanaugh's opinion is directed at answering an alleged legislative "threat" of impeachment. In this connection, the opinion goes out of its way to place the blame for the necessity of judicial action at the doorstep of veteran legislators (presumably of the opposing political party) who failed to reapportion pursuant to the 1908 constitution. (Apparently Justice Kavanaugh believed this failure was responsible for the affirmative vote in 1952 which replaced the 1908 provision with the present provision.) 367 Mich. at 176-82, 116 N.W.2d at 351-52. Justice Black's opinion, as another example, seems to be aimed indirectly, if not directly, at the general judicial philosophy of Justice Dethmers. In particular, Justice Black emphasizes Justice Dethmers' previous criticism of the Supreme Court in a speech in 1958, although no reference to the speech or the ideas expressed therein are contained in the Dethmers dissent. 367 Mich. at 249-50, 116 N.W.2d at 384-85.

162 "To Dirksenize our judgment by telling the legislature that questioned sections 2 and 4 will be judged void, as soon as that body enacts validly under original sec. tions 2 and 4 , is to perpetuate an unconstitutional body for another 2 years (and doubtless more years depending on the outcome of 4 Supreme Court elections scheduled during the next 9 months)." 367 Mich. at 253, 116 N.W.2d at 387. 